\title{
Quantitative study of the behavior of two broadcast spawners, the sea urchins Strongylocentrotus intermedius and Mesocentrotus nudus, during mass spawning events in situ
}

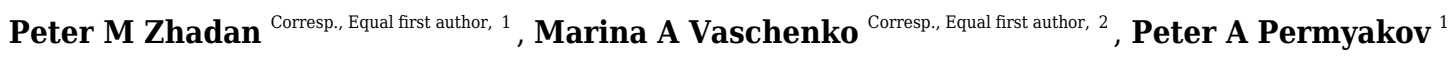 \\ 1 Department of Geochemistry and Ecology of the Ocean, V. I. Il'ichev Pacific Oceanological Institute FEB RAS, Vladivostok, Primorsky Krai, Russia \\ 2 Laboratory of Physiology, A.V. Zhirmunsky National Scientific Center of Marine Biology FEB RAS, Vladivostok, Primorsky Krai, Russia \\ Corresponding Authors: Peter M Zhadan, Marina A Vaschenko \\ Email address: pzhadan@poi.dvo.ru, mvaschenko@mail.ru
}

Background. The spatial distribution of spawners and temporal parameters of spawning in motile invertebrates with external fertilization might influence reproductive success. However, to date, data on the prespawning and spawning behaviors of broadcast spawners in the field have been scarce and mostly qualitative. The present study was intended to clarify the behavioral adaptations of two sea urchin species, Strongylocentrotus intermedius and Mesocentrotus nudus, using quantitative analysis of their behavior during mass spawning events under natural conditions.

Methods: We analyzed in situ video recordings of sea urchin behavior obtained during 6 spawning seasons (2014-2019). The total number of specimens of each sea urchin species and the numbers of spawning males and females were counted. Quantitative parameters of sea urchin spawning ( numbers of gamete batches, release duration of one gamete batch, time intervals between gamete batches and total duration of spawning) and movement (step length of spawners and nonspawners before and during spawning and changes in distances between males/nonspawners and females) were determined.

Results: For each species, 12 mass spawning events were recorded in which 10 or more individuals participated. The temporal dynamics of the numbers of males and females participating in mass spawning were well synchronized in both species; however, males began to spawn earlier and ended their spawning later than females. In both species, the most significant intersex difference was the longer spawning duration in males due to the longer pause between gamete batches. The total duration of gamete release did not differ significantly between sexes. The average duration of sperm release during mass spawning events was longer than solitary male spawning. Males and females showed significant increases in the locomotion rate $35 \mathrm{~min}$ before the start of spawning and continued to actively move during spawning. An increase in movement rate before spawning in males and females was induced by environmental factor(s). Nonspawners of both species showed increased locomotion activity but in the presence of spawning neighbors and less prominently than spawners. On a vertical surface, both echinoids moved strictly upward. On flat surfaces, males, females and nonspawners of both echinoids became closer during spawning.

Discussion: We showed that two sea urchin species with planktotrophic larvae display similar behavioral adaptations aimed at enhancing reproductive success. The high sensitivity of sea urchins, primarily males, to some environmental factors, most likely phytoplankton, may be considered a large-scale adaptation promoting the development of mass spawning events. The longer spawning duration in males and increased movement activity before and during spawning in both sexes may be considered small- 
scale adaptations promoting approach of males and females and enhancing the chances of egg fertilization. 
1 Quantitative study of the behavior of two broadcast spawners, the sea urchins

2 Strongylocentrotus intermedius and Mesocentrotus nudus, during mass spawning events in

3 situ

4

5 Peter M. Zhadan ${ }^{1}$, Marina A. Vaschenko ${ }^{2}$ and Peter A. Permyakov ${ }^{1}$

$6{ }^{1}$ Department of Geochemistry and Ecology of the Ocean, V. I. Il'ichev Pacific Oceanological

7 Institute FEB RAS, Vladivostok, Primorsky Krai, Russia

8 2Laboratory of Physiology, A.V. Zhirmunsky National Scientific Center of Marine Biology FEB

9 RAS, Vladivostok, Primorsky Krai, Russia

10

11 Corresponding Authors:

12 Peter Zhadan ${ }^{1}$

1343 Baltiyskaya Street, Vladivostok, Primorsky Krai, 690041, Russia

14 Email address: pzhadan@poi.dvo.ru

15 Marina Vaschenko ${ }^{2}$

1617 Palchevsky Street, Vladivostok, Primorsky Krai, 690041, Russia

17 Email address: mvaschenko@mail.ru 
Quantitative study of the behavior of two broadcast spawners, the sea urchins

20

21

22

23

24

25

26

27

28

29

30

31

32

33

34

35

36

37

38

39

40

41

42

43

44

45

46

47

Strongylocentrotus intermedius and Mesocentrotus nudus, during mass spawning events in

situ

Peter M. Zhadan ${ }^{1}$, Marina A. Vaschenko ${ }^{2}$ and Peter A. Permyakov ${ }^{1}$

${ }^{1}$ Department of Geochemistry and Ecology of the Ocean, V. I. Il'ichev Pacific Oceanological

Institute FEB RAS, Vladivostok, Primorsky Krai, Russia

${ }^{2}$ Laboratory of Physiology, A.V. Zhirmunsky National Scientific Center of Marine Biology FEB

RAS, Vladivostok, Primorsky Krai, Russia

Corresponding Authors: Peter M. Zhadan, Marina A. Vaschenko

Email address: pzhadan@poi.dvo.ru,mvaschenko@mail.ru

\section{ABSTRACT}

Background. The spatial distribution of spawners and temporal parameters of spawning in motile invertebrates with external fertilization might influence reproductive success. However, to date, data on the prespawning and spawning behaviors of broadcast spawners in the field have been scarce and mostly qualitative. The present study was intended to clarify the behavioral adaptations of two sea urchin species, Strongylocentrotus intermedius and Mesocentrotus nudus, using quantitative analysis of their behavior during mass spawning events under natural conditions.

Methods: We analyzed in situ video recordings of sea urchin behavior obtained during 6 spawning seasons (2014-2019). The total number of specimens of each sea urchin species and the numbers of spawning males and females were counted. Quantitative parameters of sea urchin spawning (numbers of gamete batches, release duration of one gamete batch, time intervals between gamete batches and total duration of spawning) and movement (step length of spawners and nonspawners before and during spawning and changes in distances between males/nonspawners and females) were determined.

Results: For each species, 12 mass spawning events were recorded in which 10 or more individuals participated. The temporal dynamics of the numbers of males and females participating in mass spawning were well synchronized in both species; however, males began to 
48 spawn earlier and ended their spawning later than females. In both species, the most significant 49 intersex difference was the longer spawning duration in males due to the longer pause between 50 gamete batches. The total duration of gamete release did not differ significantly between sexes. 51 The average duration of sperm release during mass spawning events was longer than solitary 52 male spawning. Males and females showed significant increases in the locomotion rate $35 \mathrm{~min}$ 53 before the start of spawning and continued to actively move during spawning. An increase in 54 movement rate before spawning in males and females was induced by environmental factor(s). 55 Nonspawners of both species showed increased locomotion activity but in the presence of 56 spawning neighbors and less prominently than spawners. On a vertical surface, both echinoids 57 58 59 60 61 moved strictly upward. On flat surfaces, males, females and nonspawners of both echinoids became closer during spawning.

Discussion: We showed that two sea urchin species with planktotrophic larvae display similar behavioral adaptations aimed at enhancing reproductive success. The high sensitivity of sea urchins, primarily males, to some environmental factors, most likely phytoplankton, may be considered a large-scale adaptation promoting the development of mass spawning events. The longer spawning duration in males and increased movement activity before and during spawning in both sexes may be considered small-scale adaptations promoting approach of males and females and enhancing the chances of egg fertilization.

\section{INTRODUCTION}

During the course of evolution, marine invertebrates with external fertilization (broadcast spawners) and feeding (planktotrophic) larvae have developed a number of reproductive adaptations ensuring successful reproduction and thereby maintaining the continuity of species.

The broadcast spawning strategy involves the release of a large number of small eggs by females and sperm by males during synchronous (often annual) spawning events (see Olive, 1992; Wangensteen, Turon \& Palacin, 2017 for review). It is generally believed that the synchronization of spawning of many individuals is provided by the ability of broadcast spawners to perceive certain environmental cues to determine the conditions appropriate for offspring development (see Mercier \& Hamel, 2009; Thorson, 1950 for review). For echinoderms and sea urchins in particular, the external synchronizers are reported to be an increased level of phytoplankton (Bronstein et al., 2016; Egea et al., 2011; Gaudette, Wahle \& 
79

80

81

82

83

84

85

86

87

88

89

90

91

92

93

94

95

96

97

98

99

100

101

102

103

104

105

106

107

108

109

Himmelman, 2006; González-Irusta, De Cerio \& Canteras, 2010; Himmelman, 1975; Starr,

Himmelman \& Therriault, 1993; Zhadan et al., 2016; Zhadan, Vaschenko \& Ryazanov, 2018), an increase or decrease in water temperature (Byrne 1990; Egea et al., 2011; Guillou \& Lumingas, 1998; Himmelman et al., 2008; King et al., 1994; Lamare \& Stewart, 1998; Tsuji et al., 1989), photoperiod (Byrne et al., 1998), different phases of the moon cycle (Coppard \& Campbell, 2005; Gaudette, Wahle \& Himmelman, 2006; Iliffe \& Pearse, 1982; Lessios, 1991; Mercier \& Hamel, 2010; Zhadan et al., 2016), time of day (Zhadan, Vaschenko \& Ryazanov, 2018) and the presence of released gametes in the environment (Reuter \& Levitan, 2010; Unger \& Lott, 1994). Although sea urchin spawning may be influenced by multiple natural factors, phytoplankton have been shown to be the most likely proximate cue for triggering spawning in some species (Gaudette, Wahle \& Himmelman, 2006; Himmelman, 1975; Starr, Himmelman \& Therriault, 1993; Zhadan, Vaschenko \& Ryazanov, 2018). Moreover, under conditions of low phytoplankton abundance, spawning failure occurs in natural populations of the sea urchin Strongylocentrotus intermedius, followed by prolonged resorption of the unspawned eggs and sperm(Zhadan, Vaschenko \& Almyashova, 2015; Zhadan et al., 2016). This phenomenon indicates that an external stimulus is extremely important for the reproduction of some species and suggests a high degree of impact of natural selection for the synchronization of spawning with environmental factors.

In motile species, behaviors aimed at reducing nearest-neighbor distances or increasing the likelihood of gamete survival and mixing may also favor fertilization success, especially at low population densities (Himmelman et al., 2008; Levitan, 2002, 2005; McCarty \& Young, 2004). A classic example of spawning organisms being located in close proximity is the pseudocopulation of ophiuroids and starfish (Himmelman et al., 2008; Slattery \& Bosch, 1993; Tominaga, Nakamura \& Komatsu, 2004). The temporal parameters of pseudocopulation differ among species. Males of dimorphic ophiuroids such as Ophiodaphne formataare constantly attached to females (Tominaga, Nakamura \& Komatsu, 2004). Males and females of the sand sea star Archaster typicus form pairs two months before spawning, and males spawn only when females release eggs (Run et al., 1988). In other sea stars and ophiuroids, approaching of males and females occurs just before or during spawning. During echinoderm mass spawning events off the Mingan Islands (the northern Gulf of St. Lawrence, Canada), many instances of pseudocopulation of the ophiuroids Ophiopholis aculeata and Ophiura robusta and sea star 
110 Asterias vulgaris as well as of approaching individuals have been observed (Himmelman et al., 111 2008).

112 Climbing onto elevated surfaces before spawning is a typical behavior for many 113 echinoderms (see Levitan, 1998; Mercier \& Hamel, 2009 for review). In cases when both sexes 114 move upward, such displacement evidently promotes approach of males and females. Spawning 115 of starfish, ophiuroids and sea urchins in situ was observed on the tops of corals, stones, and 116 even algae (Babcock et al., 1992; Gladstone, 1992; Hagman \& Vize, 2003; Himmelman et al., 117 2008; Johnson \& Ranelletti, 2017; McEuen, 1988; Minchin, 1992). The ophiuroids O. aculeata, 118 O. robusta, Ophioderma rubicundum and Ophioderma squamosissimum leave their shelters in 119 crevices before spawning and move to higher elevations (Hagman \& Vize, 2003; Himmelman et 120 al., 2008). Highly accelerated upward movement on a vertical surface immediately before and 121 during spawning was also recorded in the sea urchin Strongylocentrotus intermedius (Zhadan, 122 Vaschenko \& Ryazanov, 2018). Some starfish and ophiuroids take a characteristic pose before 123 spawning, raising the aboral disc above the bottom surface (Gladstone, 1992; Hagman \& Vize, 2003; Hendler \& Meyer, 1982; Himmelman et al., 2008). Many holothuroid species spawn with 125 their anterior ends lifted off the substratum (Hendler \& Meyer, 1982; McEuen, 1988). The 126 behavior aimed at maximal elevation of the body in the water column seems to promote gamete 127 dispersion and mixing and to increase gamete survival, mitigating their falling to the bottom and being wasted (Hendler \& Meyer, 1982; Himmelman et al., 2008).

The above observations indicate that motile echinoderms are able to change their 130 behavior before spawning events. Moreover, some species, including sea urchins, display an 131 increase in locomotion rate before spawning (Himmelman et al., 2008; Zhadan, Vaschenko \&

132 Ryazanov, 2018), prompting the suggestion that this may be the first response of mature 133 individuals to some exogenous and/or endogenous factors stimulating spawning. However, to 134 date, only a few laboratory and field studies have attempted to quantitatively assess sea urchin 135 movement in response to presumable spawning stimuli. During natural spawning events of the 136 sea urchin Mesocentrotus (=Strongylocentrotus) franciscanus, which coincided with 137 phytoplankton blooms, Levitan (2002) found no changes in the nearest-neighbor distances 138 between males and females or between nonspawners. In laboratory experiments, phytoplankton, 139 sperm and a combination of sperm and phytoplankton increased the rate of movement of 140 sexually mature Lytechinus variegates males and females up the wall of the experimental beaker, 
141 whereas only sperm and sperm+phytoplankton treatments induced vertical movement of sexually 142 immature individuals (Reuter \& Levitan, 2010). In the field experiments of McCarthy \& Young 143 (2004), sperm added to sea water did not influence the distance traveled per $1 \mathrm{~h}$ or the nearest144 neighbor distance in the sea urchin L. variegates with mature and immature gonads. Recent field 145 studies have shown that an increased phytoplankton concentration stimulates both prespawning 146 movement activity and spawning in males of the sea urchin S. intermedius (Zhadan, Vaschenko $147 \&$ Ryazanov, 2018). These findings indicate that a detailed quantitative analysis of the 148 prespawning and spawning behaviors of sea urchins during mass spawning events is needed to 149 understand whether the changes in movement activity may contribute to the enhancement of 150 fertilization success. However, to date, there have been only rare and mostly descriptive 151 observations of sea urchins' mass spawning events under natural conditions.

152 The present study was intended to obtain quantitative data on the behavior of two 153 cohabiting sea urchin species, Strongylocentrotus intermedius (A. Agassiz, 1864) and 154 Mesocentrotus nudus (A. Agassiz, 1864) (= Strongylocentrotus nudus), during mass spawning 155 events and to determine whether this behavior might contribute to the reproductive success of the studied species. To achieve this goal, we analyzed in situ video recording data of sea urchin behavior obtained during 3 spawning seasons (2017-2019). To increase the dataset, together with the data for the seasons 2017-2019, we additionally reanalyzed the data for the 2014-2016 seasons. We addressed the following: (1) how, and for how long before spawning, the behavior in two sea urchin species changes; (2) whether the distances between males and females change as a result of spawning behavior; (3) whether there is a link between spawned material and the changes in the prespawning and spawning behaviors of sea urchins; and (4) whether the behavior of nonspawning sea urchins changes during the spawning of conspecifics. We also compared the temporal characteristics of solitary and mass spawning and the dynamics of the numbers of spawners during mass spawning events in the two sea urchin species.

MATERIALS AND METHODS

\section{Study areas, sea urchins and video recordings} $\left(42.830^{\circ} \mathrm{N}, 133.691^{\circ} \mathrm{E}\right)$ and Alekseev Bay $\left(42.981^{\circ} \mathrm{N}, 131.730^{\circ} \mathrm{E}\right)$. Six separate sets of 
172 and 2015) and four in Alekseev Bay (May-June of 2016, July- September of 2017, June-

173 September of 2018 and 2019). The objects of our studies were two sea urchin species, $S$.

174 intermedius and M. nudus, which are common inhabitants of coastal communities in the study

175 areas. The timing of the studies was chosen to coincide with the spawning seasons of these

176 echinoids. For S. intermedius, it was May-September in Alekseev Bay and July-September in

177 Kievka Bay (Zhadan, Vaschenko \& Almyashova, 2017; Zhadan, Vaschenko \& Ryazanov, 2018).

178 The spawning season of M. nudus in both bays was July-August (P. Zhadan, 2020, pers. comm.;

179 this study).

180 In Kievka Bay, the studies were performed at a depth of $6 \mathrm{~m}$ on relatively flat bedrock

181 surrounded by large stones. In Alekseev Bay, the studies were performed at a depth of $2 \mathrm{~m}$ on a

182 flat bottom covered with medium-sized gravel. To register the spawning behavior of sea urchins, 183 continuous time-lapse video recording was performed with TLC200 Pro (Brinno Incorporated,

184 Taipei City, Taiwan) video cameras, which were mounted on stanchions approximately $1 \mathrm{~m}$ 185 above the bottom. The videos were taken in 1-min intervals at a resolution of $1280 \times 720$ pixels. 186 During the night, the cameras' fields of view (approximately $1.0 \times 1.5 \mathrm{~m}$ ) were illuminated by 187 LED lamps (1 W) synchronized with the cameras by a flash LED indicator, with impulse 188 duration of $1 \mathrm{~s}$.

189 To attract sea urchins to the cameras' fields of view, flat mesh containers filled with the 190 kelp Saccharina japonica (Laminariales, Phaeophyta), which is known to stimulate foraging 191 activity in M. nudus and S. intermedius (Zhadan \& Vaschenko, 2019), were used. Each container 192 (hereafter the feeder) was composed of 2 steel frames with mesh stretched across them, $1.1 \times$ $1930.75 \mathrm{~m}$ in size, and contained $30-40 \mathrm{~kg}$ of kelp. In both study areas, the density of each sea 194 urchin species was 1 to 2 ind. $\mathrm{m}^{-2}$ (Zhadan, Vaschenko \& Ryazanov, 2018). In addition, 200-300 195 specimens of $S$. intermedius in Kievka Bay $(2014,2015)$ and 200-300 specimens of each species 196 in Alekseev Bay (2016-2019) were collected within a 100- to 200-m radius of the cameras and 197 carefully transplanted within an approximately 10-m radius. Sea urchins of both species 198 themselves found the feeders, and within approximately 2 days, 30-70 individuals of each 199 species populated the feeders. The feeders were replaced every 2-3 weeks when approximately $20080 \%$ of laminaria was consumed by sea urchins. Sea urchins were carefully transferred from the 201 old feeders to the bottom, and then they found themselves the feeders with fresh laminaria and 202 populated them within several hours. It took approximately 5 min to change one feeder. 
In both bays, four video cameras were used. In Kievka Bay, each camera was directed at

204

205

206

207

208

209

210

211

212

213

214

215

216

217

218

219

220

221

222

223

224

225

226

227

228

229

230

231

232

233

the feeder. The entire area of the feeder and an additional 5-10 $\mathrm{cm}$ around its edges were in the cameras' fields of view. In Alekseev Bay, where two feeders were located close to the vertical wall of the concrete pier (2016) or to a pyramid built of stones (2017-2019), two cameras were directed at the feeders, and two others were directed at the pier wall or the surface of the stone pyramid.

\section{Video recording and statistical analyses}

Just after the changes the feeders, isolated spawning males of M. nudus but not S. intermedius were noted on them. Therefore, to exclude the possibility that our manipulations could affect the results, video recordings taken for $8 \mathrm{~h}$ after the feeders were changed were not analyzed. During spawning, the sexes of both sea urchin species are easily distinguishable due to different colors of gametes: white in males and orange and light-yellow in females of $S$. intermedius and $M$. nudus, respectively. The recorded videos were viewed frame by frame, and the total number of specimens of each sea urchin species in the cameras' fields of view and the numbers of spawning males and females were counted. In cases when at least 10 individuals took part in spawning for at least $1 \mathrm{~h}$, we used the term "mass spawning".

By means of the free software "Tracker" for video analysis (www. open sourcephysics.org/items/detail.cfm?ID=7365) we traced the spawning males and females with an interval of $1 \mathrm{~min}$. The distance between two successive positions of the sea urchin (1 min apart) was defined as the step length (Lauzon-Guay, Scheibling \& Barbeau, 2006; Zhadan \& Vaschenko, 2019). The cell size $(2 \times 2 \mathrm{~cm})$ of the feeder mesh was used as a scale. For males and females participating in mass spawning events, the tracing was started $60 \mathrm{~min}$ before the beginning of spawning of the first individual and finished when the last individual ceased to spawn (see Table S1 for raw data). Each track lasted approximately 180 min. For nonspawning sea urchins that were present on the feeders during mass spawning events, the duration of tracing was the same as that for spawners. In cases when sea urchins spawned alone or the spawners' numbers were less than 10, the tracing began 60 min before the start of spawning of each spawner and lasted approximately $180 \mathrm{~min}$.

Only full sea urchin tracks were included in the statistical analysis (see Table S1 for raw data). Exceptions included the tracks of sea urchins that spawned on the vertical surfaces of the 
234 pier wall or stone pyramid. In these cases, sea urchins before and during spawning moved strictly 235 upward with a high speed and left the camera's field of view before it was safe to conclude that 236 they had finished spawning.

237 The beginning and end of the release of each gamete batch and duration of the intervals

238 between the gamete batches were determined with an accuracy of 1 min. Total spawning 239 duration was determined as a sum of total duration of gamete release and total duration of the 240 intervals between the gamete batches (see Table S1 for raw data). In the cases when spawning of 241 the specimen was recorded on only one frame, the individual spawning duration was considered 242 to be $1 \mathrm{~min}$. To analyze the sex-specific, species-specific and habitat-related differences in 243 quantitative parameters of spawning (the release duration of one gamete batch, total duration of 244 gamete release, time intervals between gamete batches, total duration of the intervals between 245 the gamete batches and total duration of spawning) and to compare the time to reach the 246 maximum numbers of spawning males and females participating in mass spawning events, the 247 corresponding datasets were created and tested for adherence to a normal distribution 248 (D'Agostino and Pearson omnibus normality test, $P<0.05$ ). Since most of the datasets were not 249 normally distributed, the nonparametric Mann-Whitney test, Wilcoxon matched-pairs signedrank test and Spearman's rank-order correlation were used. The same procedure was performed to compare temporal parameters of solitary and mass spawning in males of both sea urchin 252 species.

To determine the moment of change (inflection point) in the locomotion rate of sea urchins before spawning, the 180-min time series of step lengths of spawning individuals were combined into 4 datasets, separately for each species and each sex, and aligned so that the beginnings of spawning of all individuals coincided. Within each dataset, the 60-min interval preceding the start of spawning was segmented by 11 possible inflection points ( 5 min apart). Each such point segmented the time-series dataset into two samples, one of which was assumed as the expected period before the beginning of change in sea urchin locomotion rate ("before start") and the other as the expected period after the beginning of locomotion change ("after start"). Thus, 11 datasets were obtained, which were then compared using a nonparametric twosample permutation test (Efron \& Tibshirani, 1993). The test statistic $\Theta$ was estimated as the absolute difference between the medians, i.e., $\Theta=\left|M e_{\text {before start }}-M e_{\text {after start }}\right|$. The accumulated 
265 of cases when the absolute difference between two medians after data permutation $\left(\Theta_{\text {Perm }}\right)$ was

266 higher than our observed result $\left(\Theta_{E x p}\right)$. The first inflection point with $A S L \leq 0.01$ was determined

267 as a moment of statistically significant change in the locomotion rate of the sea urchins. The time

268 interval preceding this point was defined as the "control interval", and the following interval was

269 defined as the "prespawning interval", which ended with the onset of spawning. The 35-min

270 interval after the beginning of spawning was defined as the "spawning interval".

271 To analyze the sex-specific and species-specific differences in quantitative parameters of

272 movement as well as to determine whether the locomotion rate in nonspawners changes during

273 mass spawning events, the datasets on the step length of spawners and nonspawners of each sea

274 urchin species measured during the control, prespawning and spawning intervals were pooled

275 into corresponding datasets, checked for adherence to a normal distribution and tested with the

276 Kruskal-Wallis test followed by Dunn's multiple comparison test.

277 To determine whether sperm released by the males that began to spawn first during mass

278 spawning events (hereafter "leading males") influenced the locomotion rate of males that began

279 to spawn $40 \mathrm{~min}$ later when there were already approximately 50\% spawning males (hereafter

280 "outsider males"), the step lengths of these two groups of males measured during the

281 prespawning period were compared. The datasets on step lengths for leading males were

282 supplemented with data on step lengths of males that spawned first in the cases that were not

283 referred to as mass spawning events. After checking for adherence to a normal distribution, the

284 data on step lengths of leading and outsider males of each sea urchin species were compared by

285 the Mann-Whitney test.

286 To determine whether spawning males, females and nonspawning individuals come

287 closer together during mass spawning, 2 analyses were performed. First, the distances from

288 males, females and nonspawners to their common center of mass were determined. When

289 calculating the center of the sea urchin mass, the conditional mass of males or females was taken

290 as a multiple of the time of gamete release, and the conditional mass of nonspawners was taken

291 as a value of 1. Second, the distances from each of the males and nonspawners to the center of

292 mass of females were measured. Then, the differences between the distances measured $1 \mathrm{~min}$

293 apart during the 25-min control interval and during the spawning period, from the beginning of

294 spawning to its completion in $95 \%$ of males, were determined, and the medians of these

295 differences for the control and spawning periods were compared using the Mann-Whitney test. 
296 For graphical representation, the values of the displacement of each individual relative to its

297 location at the beginning of the control interval were calculated 1 min apart. As these values

298 were normally distributed, they are presented as the mean and $95 \%$ confidence interval.

299

300 RESULTS

301 General characteristics of sea urchin spawning

302 In Kievka Bay in 2014-2015, spawning was recorded in 86 males and 6 females of $S$.

303 intermedius and in 21 males of M. nudus. In Alekseev Bay in 2016-2019, spawning was

304 recorded in 510 males and 19 females of $S$. intermedius and in 824 males and 39 females of $M$.

305 nudus. Spawning occurred both in the presence and absence of spawning females. In the absence

306 of females, the maximum numbers of S. intermedius and M. nudus spawning males were 11 and

30720 , respectively. For the entire duration of the observations, only a few females that spawned in

308 the absence of males were recorded: 2 females of $S$. intermedius, which spawned on different

309 days, and 2 females of M. nudus, which began to spawn with an interval of 4 min. The ratios of

310 females to males for all spawning individuals were 1:24 for $S$. intermedius and 1:22 for $M$.

311 nudus.

312 Calculations made from the total sea urchin number in the camera field of view, number

313 of spawners and the female/male ratio show that males seem to be able to spawn several times

314 during the spawning season. This is clearly demonstrated by a video recording obtained by one

315 of the cameras, which in 2018 (June 11-17) recorded 3 mass spawning events with the

316 participation of 41 males of M. nudus. Another 27 males spawned during the intervals between

317 mass spawning events. Taking into account that the total sea urchin number in the camera field

318 of view during this week decreased from 41 to 34 individuals and that the female/male ratio was

$3191: 1$, one may calculate that each of the males spawned approximately 3 times during this period.

320 The total duration of sperm release during this week decreased by 3 times, but this change was

321 not significant (Mann-Whitney test, $U=15, P=0.08$ ).

322 For each species, 12 mass spawning events were recorded, in which 10 and more

323 individuals participated (Table 1). The percentage of spawning individuals ranged from $18 \%$ to

$32478 \%$ of the total number of sea urchins in the cameras' fields of view. A total of 142 males and

32515 females of $S$. intermedius and 183 males and 34 females of $M$. nudus participated in mass

326 spawning. Thus, the numbers of $S$. intermedius and M. nudus males participating in mass 
327 spawning were 4 and 5 times lower and the numbers of females were 2.1 and 1.7 times lower,

328 respectively, than the corresponding total numbers of spawning individuals. Both sexes

329 participated in 8 of 12 spawning events for S. intermedius and in 10 of 12 spawning events for

330 M. nudus. The ratios of females to males were 1:9 and 1:5 for S. intermedius and M. nudus, 331 respectively.

332 Spawning occurred at dusk or at night in 19 of 24 mass spawning events recorded for 333 both species (see Table S1). Twelve of 24 mass spawning events took place within the range 334 from 0 to 4 days near the new moon, 2 events were recorded the day before the full moon, 3 335 events occurred when the moon was in waxing phase (first quarter), and 7 events were observed 336 when the moon was in waning phase (third quarter) (see Table S1).

$337 \quad$ Despite the spawning seasons of S. intermedius and M. nudus overlap in the areas studied 338 and the simultaneous spawning of several individuals of both sea urchins was sometimes 339 observed, no one case of synchronous mass spawning with participation of 10 and more 340 individuals of each species was recorded. However, on July 13, 2018, a case of simultaneous 341 spawning of 29 individuals (23 males and 6 females) of M. nudus and 5 individuals (4 males and 3421 female, i.e., $<10$ individuals) of S. intermedius was recorded in Alekseev Bay (see Sheet 18 in

343 Table S1). One can see that spawning of both sea urchin species is synchronous.

344

345 Temporal parameters of spawning

346 Males and females of both sea urchin species released gametes in batches. The number of

347 batches in males varied from 1 to 10 in S. intermedius (median =3) and from 1 to 9 in M. nudus

348 (median =2) and was significantly higher in $S$. intermedius (Mann-Whitney test, $U=4534, P=$ 349 0.0183). The numbers of batches in females of the two species did not differ significantly (range 350 from 1 to 6 , median $=2$ for $S$. intermedius and range from 1 to 6 , median $=1$ for $M$. nudus, 351 Mann-Whitney test, $U=138.5, P=0.205$ ). The release duration of one gamete batch (the time 352 in which a gamete clot was present in the area near the gonopores), time intervals between 353 gamete batches and total duration of spawning ranged widely (Table 2). Analysis of intersex 354 differences showed that in both sea urchin species, the spawning duration of males was longer 355 than that of females ( $P=0.039$ and $P=0.009$ for $S$. intermedius and $M$. nudus, respectively) 356 because although the total duration of gamete release did not differ significantly between sexes 357 ( $P=0.66$ and $P=0.58)$, the total duration of intervals between gamete batches was significantly 
358 higher in males $(P=0.001$ and $P<0.0001)$ (Table 2$)$. Analysis of interspecific differences

359 showed that in males, the release duration of one gamete batch, total duration of gamete release,

360 total duration of intervals between gamete batches and total duration of spawning were

361 significantly higher in S. intermedius than in M. nudus (Table 2). In females of the two sea

362 urchin species, there were no significant differences in any of the spawning parameters studied.

363 Comparison of spawning parameters in S. intermedius sea urchins living in different bays

364 showed that intersex differences were slightly more pronounced in sea urchins from Alekseev

365 Bay (Table 3). In S. intermedius males from Alekseev Bay, all temporal parameters of spawning 366 were significantly higher than those in Kievka Bay (Table 3). In S. intermedius females from 367 different bays, there were no significant differences in any of the spawning parameters.

368 A comparison of the temporal parameters of solitary and mass spawning in males of $S$. 369 intermedius and M. nudus from Alekseev Bay showed that in both species, the duration of 370 release of one gamete batch and the total duration of gamete release were significantly higher 371 during mass spawning events (Table 4). In S. intermedius males, the total duration of intervals 372 between gamete batches and total spawning duration were also higher during mass spawning.

373

\section{Dynamics of mass spawning}

375 The spawning dynamics of males and females of both sea urchin species were generally similar:

376 the number of spawners gradually increased, reaching a maximum, and then decreased to zero

377 (Figs. 1A, 1B). The spawning males demonstrated similar dynamics both in the presence and 378 absence of females (Figs. 1C, 1D). Figure 2 shows the dynamics of the total numbers of males 379 and females of S. intermedius (Fig. 2A) and M. nudus (Fig. 2B) for all events of mass spawning.

380 In most cases, the spawning duration of both sea urchin species was approximately $100 \mathrm{~min}$

381 (Figs. 2A, 2B). However, in 2 of 12 mass spawning events of S. intermedius, a second spawning 382 wave took place, in which approximately $55 \%$ and $80 \%$ of females and males of the first 383 spawning wave participated, respectively (Fig. 2A).

$384 \quad$ In most mass spawning events of $S$. intermedius, the males started to spawn first (Fig.

385 2A). In 2 of 12 mass spawning events, S. intermedius females began to spawn first, but one of 386 these cases was doubtful because when the female shifted 4 min after the start of spawning, the 387 spawning male was found underneath. M. nudus males began to spawn first in all 12 mass 388 spawning events (Fig. 2B). In all cases, males of both species finished to spawn after females 
389 (with exception of one case when the female finished to spawn simultaneously with males, see 390 Sheet 24 in Table S1).

$391 \quad$ On average, S. intermedius and M. nudus females began to spawn $26.5(-4-43)$ min and 39224 (1-67) $\min$ (the data are presented as median and range) after the start of the first male 393 spawning, respectively, when a great number of males had already spawned, and finished to 394 spawn 12.0 (1-214) and $15.5(0-70)$ min before the last male spawning (Figs. 1A, 1B, 2A, 2B).

395 Although the females began to spawn later than the males, the times to reach the maximum 396 numbers of spawning males and females did not differ significantly (Wilcoxon matched-pairs 397 signed-rank test: $n=8, W=-18, P=0.16$ for $S$. intermedius and $n=10, W=-2, P=0.95$ for $M$. 398 nudus). Spearman's correlation analysis revealed significant positive relationships between the 399 numbers of simultaneously spawning males and females for both species (Spearman's $r=0.722$ 400 and 0.845 for $S$. intermedius and $M$. nudus, respectively, $P<0.0001$ ).

401

\section{Movement activity of sea urchins}

403 Our data show that sea urchins of both species increased their movement activity shortly before

404

405

406

407

408

409

410

411

412

413

414

415

416

417

418

and during spawning. A significant increase in step length in both sexes of both sea urchin species occurred from 30 to 35 min before the start of spawning (identified by the intersection of the threshold value of $A S L=0.01$ ) (Figs. 3A-3D).

During the prespawning interval, the average step length in males and females of both species was significantly higher than that in the control (Table 5). During the spawning interval, both sexes of M. nudus and males of S. intermedius accelerated even more, while S. intermedius females slowed down (Table 5). As the end of mass spawning approached, the movement rate in both sexes of both species gradually decreased (Figs. 3A - 3D).

Leading males that began to spawn first during mass spawning events showed a significant increase in the average step length in both species during the prespawning period compared with the control, followed by further acceleration during the spawning interval (Fig. 4; Table 5). This finding indicates that accelerated locomotion of sea urchins before spawning resulted from external cues.

Comparison of the time series of step length of two groups of spawning males, leading males and outsider males, during the prespawning period showed no significant differences 
419 (Table 6). This result indicated that sperm of leading males did not influence the locomotion rate 420 of outsider males during the prespawning period.

421 The number of females that spawned in the absence of other spawners was too small for 422 statistical analysis (two S. intermedius females and two M. nudus females). However, it should 423 be noted that in the only $S$. intermedius female, which undoubtedly began to spawn first during 424 mass spawning, the average step length during the prespawning period was 3.9 times longer than 425 that during the control period, and the average prespawning step length in two M. nudus females, 426 which spawned in the absence of spawning males, was 2.1 times longer.

427 Analysis of the temporal dynamics of step length in nonspawning individuals showed that 428 in both species, there was no significant difference in locomotion rate between the control and 429 prespawning intervals, while a small but significant increase in this parameter occurred during 430 the spawning interval (Fig. 5; Table 5).

431 Despite the absence of complete synchronization of the changes in locomotion rate, a 432 significant positive correlation between the time series of step length of males and nonspawning 433 individuals was found in 8 out of 12 mass spawning events for $S$. intermedius and in all 12 mass 434 spawning events for M. nudus (ranges of Spearman's $r$ from 0.55 to 0.11 and $P$ from $<0.0001$ to 4350.31 for $S$. intermedius, Spearman's $r$ from 0.58 to 0.27 and $P$ from $<0.0001$ to 0.004 for $M$. 436 nudus).

437

438 Spatial distribution of sea urchin males and females during spawning

439 Measurement of the distances from males, females and nonspawners to their common center of 440 mass revealed significant approach of sea urchins of both species during the spawning period 441 (Fig. 6; Table 7). Measurement of the distances from males and nonspawners to the center of 442 mass of females revealed significant approach during spawning in both sea urchin species (Fig. 443 7; Table 7). Fig. 7 demonstrates the dynamics of the mean difference between the initial and 444 measured 1-min interval distances from males and nonspawners to females. Since only one 445 female took part in 5 of 8 mass spawning events of $S$. intermedius with the participation of both 446 sexes, and in one case, two females were close to each other, the data in Fig. 7A mainly reflect a 447 decrease in the distance from males and nonspawners to females. Since a larger number of 448 females participated in the mass spawning events of M. nudus (Table 1), the data in Fig. 7B 449 reflect a decrease in the distance from males and nonspawners to the area where females moved 
450 during spawning. For both sea urchin species, the displacement of males towards females was

451 approximately two times higher than that of nonspawning individuals.

452 It should be noted that there was variability between mass spawning events in the median

453 distances of males and nonspawners to the center of mass of females: the distances could

454 decrease (in most cases), increase or remain almost unchanged (see Table S1 for raw data).

455 The spatial distribution of sea urchins during spawning on the vertical surface (pier wall)

456 or inclined surface of stone pyramids was significantly different from that on flat food substrates.

457 Males and females of both species moved strictly upward both before and during spawning.

458 Spawning males, reaching the top of a large stone, continued to actively move along its surface

459 in the absence of females. In cases when there was a spawning female nearby, the males slowed

460 down or stopped. In contrast, females usually stopped active movement during spawning after

461 reaching the top of the stone. S. intermedius females also displayed similar behaviors on food

462 substrates when they were on top of other individuals. In M. nudus, the formation of such groups

463 was not recorded in any of the mass spawning events.

464

465

466

467

468

469

470

471

472

473

474

475

476

477

478

479

480

\section{DISCUSSION}

Despite the high density of sea urchins on food substrates, only 24 mass spawning events (each of 10 and more spawners) were recorded for both species over 6 spawning seasons (2014-2019), in which approximately 4 times fewer sea urchins were involved compared with the total number of spawners. This finding indicates that in S. intermedius and M. nudus, mass spawning is a relatively rare phenomenon that apparently occurs due to the complex interaction of both intrinsic (i.e., gonad maturity) and extrinsic (some environmental cue(s), primarily phytoplankton), factors. The application of continuous around-the-clock time-lapse video recordings and feeders with kelp attractive to sea urchins allowed us to perform a high-temporalresolution (at 1-min intervals) quantitative analysis of the behaviors of $S$. intermedius and $M$. nudus before and during mass spawning events under natural conditions. To the best of our knowledge, this is the first such analysis to examine the representatives of mobile broadcast invertebrates with planktotrophic larvae. The high temporal resolution of the video recording method provides an opportunity for the mutual interpretation of results from laboratory and field studies, and long-term around-the-clock observations allowed us to replenish the data on the behavior of broadcast invertebrates during mass spawning obtained in situ by diving.

Peer) reviewing PDF | (2020:10:53402:1:0:NEW 28 Dec 2020) 
482 Temporal characteristics and quantitative dynamics of mass spawning are similar in $S$. 483 intermedius and $M$. nudus

484 Males and females of both sea urchin species exhibited an intermittent ("pulse") pattern of 485 spawning, as shown earlier for S. intermedius (Zhadan, Vaschenko \& Ryazanov, 2018). The most 486 significant difference in temporal parameters of spawning was the longer duration of male spawning in terms of both intersex comparison (in both species, males spawned longer than females) and interspecies comparison (S. intermedius males spawned longer than M. nudus males). This result is consistent with the conclusion of Lotterhos \& Levitan (2010) based on an analysis of data reported in studies on spawning duration in males and females of 13 taxonomic groups of broadcast invertebrates, including echinoderms. However, in this review, the spawning process of 3 sea urchin species (Strongylocentrotus franciscanus, S. droebachiensis and

493 494 495 496 497 498 499

500

501

502

503

504 505 506 507 508 509

Diadema antillarum) was characterized as continuous ("plume") based on occasional diving observations. In our studies, along with the intermittent ("pulse") pattern of spawning, we showed that in S. intermedius and M. nudus, the longer spawning duration of males was due to the longer pause between sperm batches, while there were no sex differences in the total duration of gamete release.

Taking into consideration that the duration of gamete release in our study was assessed by the presence of gamete clot on the aboral surface of sea urchin test, a question may arise whether different spawning duration of males and females may be due to different physical properties of sperm and eggs and the influence of water advection on gametes' dispersion. To date, only a few studies addressed these issues in sea urchins (Thomas, 1994; Yund and Meidel, 2003; see also Crimaldi and Zimmer, 2014 for review). Based on the comparison of the retention times of eggs and sperm on the tests of three morphologically different sea urchin species (Tripneustes gratilla, Echinometra mathaei and Colobocentrotus atratus) under different water velocity (Thomas, 1994 ) and our results on temporal parameters of S. intermedius and M. nudus spawning, we may suggest that the earlier cessation of spawning in females of $S$. intermedius and M. nudus compared to males during mass spawning events is due to longer spawning duration of males but not different physical properties of female and male gametes.

In both $S$. intermedius and M. nudus, the temporal dynamics of the numbers of males and females participating in mass spawning were well synchronized, so that the maximum numbers 
512 of simultaneously spawning sexes coincided. Currently, to the best of our knowledge, there is

513 surprisingly little information on the temporal patterns of spawning in situ both for sea urchins

514 and other groups of broadcast spawners. In terms of quantification of the dynamics of mass

515 spawning, the studies of in situ spawning of the sea cucumber Cucumaria frondosa, the

516 echinoderm species with long-lived planktonic lecitothrophic larva, seem to be the most

517 comprehensive (Hamel \& Mercier, 1995, 1990). Mass spawning event started from the spawning

518 of isolated males. The number of males reached maximum (83\%) after $10 \mathrm{~h}$, whereas maximum

519 number (87\%) of females was recorded after $12 \mathrm{~h}$ when the males' number was less than $32 \%$.

520 Thus, the maxima of spawning activity in males and females of $C$. frondosa did not coincide.

521 However, this delay between the peaks of male and female spawnings could have a benefit for

522 fertilization success because it allows to attain a maximum concentration of sperm in the water

523 column prior to female spawning (Hamel \& Mercier, 1996). We believe that the differences in

524 the temporal dynamics of the numbers of spawners of $C$. frondosa (Hamel \& Mercer, 1995) and

525 S. intermedius and $M$. nudus (our study) during mass spawning can be explained by interspecific

526 variations in reproductive physiological adaptations and behavior associated with different life-

527 history models and aimed at optimization of gamete dispersion and fertilization success in each

528 species.

$529 \quad$ Generally, males of S. intermedius and M. nudus exhibited much more active spawning

530 behavior than females. First, they began to spawn earlier and ended spawning later than females

531 in all cases except for one mass spawning event when one $S$. intermedius female undoubtedly

532 began to spawn before males. Moreover, males of both sea urchin species were capable of

533 spawning in the absence of females, demonstrating temporal dynamics of spawner numbers

534 similar to those during mass spawning with the participation of both sexes. In contrast, females

535 began to spawn after several males had already spawned, and over 6 spawning seasons, for each

536 species, only two cases were recorded as not belonging to mass spawning when females spawned

537 in the absence of males. Our observations support the currently accepted view that in broadcast

538 spawners, males predominantly spawn before females (see Levitan, 1998; Mercier \& Hamel,

539 2009; Thorson, 1950 for review). For sea urchins, rare exceptions have been encountered in field

540 studies, for example, spawning of $S$. droebachiensis females in the absence of males (Pearse et

541 al., 1988). 
542

543

544

545

546

547

548

549

550

551

552

553

554

555

556

557

558

559

560

561

562

563

564

565

566

567

568

569

570

571

572

Second, the numbers of males participating in mass spawning were significantly higher than those of females (the female/male ratios were 1:9 and 1:5 for S. intermedius and M. nudus, respectively). This is significantly different from the sex ratio in the natural populations of these species, which is close to 1:1 (Zhadan, Vaschenko \& Ryazanov, 2018; P. Zhadan, 2020, pers. comm.). Similar female/male ratios during mass spawning in the field were found for other sea urchin species, such as Strongylocentrotus purpuratus (1:4, Levitan, 2002), M. franciscanus (1:8, Levitan, 2002) and S. droebachiensis (1:4, Himmelman et al., 2008).

The significant excess of spawning males over the number of spawning females can be explained in several ways. First, males develop the ability to release gametes earlier than females and retain this ability after the completion of female spawning, as was shown for $S$. intermedius (Zhadan, Vaschenko \& Almyashova, 2015; Zhadan, Vaschenko \& Ryazanov, 2018). The same sexual maturity pattern was reported for males of the sea urchin Lytechinus variegates (Reuter \& Levitan, 2010). Second, males seem to be able to spawn several times during the spawning season (Zhadan, Vaschenko \& Ryazanov, 2018; this study). Third, males seem to be more sensitive to external triggers of spawning than females. Consistent with this suggestion, laboratory experiments demonstrated the higher sensitivity of males to external stimuli such as phytoplankton and sperm for the sea urchins S. droebachiensis and L. variegatus, mussel Mytilus californianus and crown-of-thorns starfish Acanthaster cf. solaris (Caballes \& Pratchett, 2017; Reuter \& Levitan, 2010; Starr, Himmelman \& Therriault, 1990).

As proposed previously by several researchers, the dynamics of the numbers of spawners during mass spawning of sea urchins are likely to form due to the presence of positive feedback (Reuter \& Levitan, 2010; Starr, Himmelman \& Therriault, 1990). Thus, spawning products of the individuals most sensitive to environmental factors stimulate the spawning of neighbors, as shown in laboratory experiments in which sperm alone induced spawning in L. variegates (Reuter \& Levitan, 2010) and a combination of phytoplankton and sperm had a synergistic effect on spawning induction in S. droebachiensis females (Starr, Himmelman \& Therriault, 1992). It should be noted, however, that in the other laboratory and field experiments, no effect of waterborne gametes of $L$. variegatus on spawning induction in sexually mature conspecifics of both sexes was found (McCarthy \& Young, 2004). Our results showed that in both S. intermedius and M. nudus, the duration of sperm release during mass spawning events was longer than that of solitary spawning. These findings indicate, on the one hand, that during mass spawning,

Peer) reviewing PDF | (2020:10:53402:1:0:NEW 28 Dec 2020) 
573 fertilization success may be enhanced by not only the larger number of spawners but also the 574 higher intensity of gamete release. On the other hand, our results suggest that (1) water-borne 575 gametes cannot be considered a primary cue for the induction of mass spawning and (2) one of 576 the reasons for the development of mass spawning events in broadcast spawners may be 577 favorable environmental conditions for the stimulation of spawning, for example, phytoplankton 578 concentrations higher than those during solitary spawning. Our previous field studies showed 579 that an increase in phytoplankton concentration triggers spawning in natural $S$. intermedius 580 populations (Zhadan, Vaschenko \& Almyashova, 2015; Zhadan et al., 2016; Zhadan, Vaschenko $581 \&$ Ryazanov, 2018). The timing, duration and completeness of spawning at the population level 582 clearly depended on phytoplankton abundance during the spawning season. In the present study, 583 we showed that the temporal parameters of spawning in $S$. intermedius males were different in

584

585

586

587

588

589

590

591

592

593

594

595

596

597

598

599

600

601

602 603 bays with different levels of phytoplankton. In the bay with the higher phytoplankton level, $S$. intermedius males exhibited significantly longer durations of gamete release, intervals between gamete batches and total spawning processes. Considering that most mass spawning events in $S$. intermedius and M. nudus occurred at night and close to new or full moon phases, the nighttime and lunar phases may be additional environmental factors increasing the probability of mass spawning.

In the present work, we did not include data on the role of phytoplankton in the stimulation of spawning in M. nudus. Our preliminary data provide evidence that an increased concentration of phytoplankton triggers spawning in the M. nudus population (P. Zhadan, 2020, pers. comm.). However, the relationships between spawning and environmental factors for this species are more complex than those for $S$. intermedius. At a low concentration of phytoplankton in the environment, mature gametes accumulated in M. nudus gonads and were released during storm events. These data will be the subject of a future article.

\section{Sea urchins increase movement activity before and during mass spawning}

In a previous study, we reported that $S$. intermedius males began to move actively just before spawning and retained this activity during the spawning process (Zhadan, Vaschenko \& Ryazanov, 2018). In the present work, a precise time was determined when an increase in the locomotion rate of sea urchins happened before spawning. In both sexes of S. intermedius and $M$. nudus, this phenomenon occurred 35 min before the start of spawning. M. nudus males and 
604 females and S. intermedius males gradually increased the locomotion rate right up to the time of

605 spawning, while $S$. intermedius females reached a plateau in the average step length

606 approximately $15 \mathrm{~min}$ before the beginning of spawning and exhibited a lower locomotion rate

607 during spawning than males (Fig. 3; Table 6). Many S. intermedius females stopped moving after

608 climbing to the top of a stone or to another individual. These results are consistent with our

609 previous conclusion about the increased movement activity of $S$. intermedius males during

610 spawning (Zhadan, Vaschenko \& Ryazanov, 2018).

611 Another important finding of this study was that sea urchins that started to spawn first

612 during mass spawning (leading males) as well as males that spawned alone increased their

613 movement rate before spawning in the absence of other spawning individuals. This observation

614 clearly indicates that the increase in locomotion activity in S. intermedius and M. nudus before

615 spawning is due to environmental factor(s). Moreover, we found no differences in the

616 prespawning locomotion rate between leading males and outsider males, which started to spawn

617 when the sperm of leading males was already present in the environment. Nevertheless, this

618 finding cannot exclude the influence of sperm as a factor contributing to the stimulation of

619 spawning in sea urchins. Our results showing that nonspawning individuals of both species

620 increased locomotion activity in the presence of spawning males and females suggest a possible

621 effect of released gametes on the movement activity of nonspawners during mass spawning

622 events. This suggestion is congruent with the results of laboratory experiments in which

623 phytoplankton and/or sperm treatments stimulated spawning behavior defined as climbing up the

624 sides of the beaker in L. variegatus males and females, whereas only sperm and the combination

625 of phytoplankton and sperm stimulated such a behavior in sexually immature individuals (Reuter

626 \& Levitan, 2010).

627 Simultaneously, we observed that in some cases, nonspawners began to actively move

628 before their neighbors started to spawn. Sheet 34 in Table S1 demonstrates that on the nonfood

629 substrate where there were $4 M$. nudus individuals, 2 females and 2 nonspawners, the

630 nonspawners began to actively move before the females began to spawn. Moreover, we also

631 observed that in September, after all M. nudus individuals had already spawned, with an increase

632 in the concentration of phytoplankton up to 5-10 $\mu \mathrm{g} 1^{-1}$, sea urchins moved from the feeders to a

633 stone pyramid, and with a decrease in phytoplankton concentration, they returned again to the

634 food substrate. These observations suggest that immature sea urchins have the ability to perceive 
635 some environmental signal(s), in the case of their high intensity, which stimulates spawning 636 behavior.

637

638 Sea urchin males and females become closer during mass spawning

639 One of the most interesting questions concerning the reproductive behavior of sea urchins, to

640 which there is still no answer, is the question of whether sea urchins approach each other during 641 spawning. On flat food substrates, the movement of spawning males of $S$. intermedius and $M$.

642 nudus appeared multidirectional (Zhadan, Vaschenko \& Ryazanov, 2018; this study). However,

643 comparison of the distances between males and females measured during the control and

644 spawning periods revealed that during spawning, males and females of both sea urchin species

645 became significantly closer. Moreover, nonspawners also approached females, although this

646 approach was less pronounced than that between males and females.

647 To date, due to rare direct field observations of sea urchin spawning, information on the

648 spatial distribution of sea urchin species before and during spawning has been scarce. The sea

649 urchin S. droebachiensis formed no spawning aggregations during echinoderm mass spawning

650 events off the Mingan Islands in the northern Gulf of St. Lawrence in eastern Canada

651 (Himmelman et al., 2008), whereas sea urchins T. gratilla off the island of Maui (Hawaii)

652 spawned within small groups of 2-5 (Johnson \& Ranelletti, 2017). One case of L. variegates

653 spawning in an aggregation of several hundred sea urchins was observed in St. Joseph Bay,

654 Florida (Reuter \& Levitan, 2010). To the best of our knowledge, the study reported by Levitan

655 (2002) is the only work where nearest-neighbor distances between spawning and nonspawning $S$.

656 franciscanus sea urchins during mass spawning events in the field were determined. Based on

657 the data on the distribution of sea urchins that were mapped at 30-min intervals for $2 \mathrm{~h}$, it was

658 concluded that spawners and nonspawners did not become more aggregated during spawning. In

659 our study, sea urchin trajectories were traced at 1-min intervals for $3 \mathrm{~h}$, and the changes in

660 distances from the mass centers of females to males and nonspawners were determined. This

661 approach allowed us to show that sea urchins of $S$. intermedius and M. nudus did not form true

662 aggregations before and during mass spawning events, but they undoubtedly approached each

663 other. The most significant changes in the distances between spawning and nonspawning $S$.

664 intermedius and M. nudus sea urchins occurred during the first 50-60 min after the beginning of

665 mass spawning (Fig. 7), and the ranges of these changes varied widely, as males/nonspawners 
666 both approached the females and moved away (Table 7). Therefore, the time resolution of 30 $667 \min$ (Levitan, 2002) did not seem to be sufficient to detect the changes in nearest-neighbor 668 distances between sea urchins during spawning.

669 Since fertilization success in sea urchins depends on the distance between the male and 670 female (Levitan, 2002, 2005), their approach during mass spawning is important for reproductive 671 success. The meaning of the approach between nonspawning individuals and females is not very 672 obvious. In this regard, a question arises concerning whether spawning males and nonspawning 673 individuals exhibit similar behaviors due to their responses to some chemical cues (pheromones) 674 that are released together with gametes shed by conspecifics, most likely females. The last 675 supposition is based on our observations that despite females moving more actively than males 676 immediately before spawning, they usually stopped after climbing the elevated surface, followed 677 by the start of spawning. Simultaneously, after the beginning of spawning, males accelerated in 678 the absence of females but stopped near females.

679 Both experimental and field studies show that sea urchins use chemosensation to avoid 680 predators as well as to find food (Campbell et al., 2001; Mann et al., 1984; Spyksma, Taylor \&

681 Shears, 2017; Zhadan \& Vaschenko, 2019). Genomic analysis suggests that an elaborate

682 chemosensory system involving several hundred putative chemoreceptor genes, in particular 683 those encoding olfactory receptors, operates in sea urchins (Burke et al., 2006; Raible et al.,

684 2006). However, to date, there is no information on the presence and chemical nature of 685 pheromones in sea urchins. Recently, mass spectrometry, genomic and proteomic analyses were 686 performed to identify the protein composition of water-borne plumes released from aggregating 687 spawning crown-of-thorn starfish (Acanthaster planci) (Hall et al., 2017). The proteins secreted

688 by $A$. planci have been shown to consist largely of signaling factors and hydrolytic enzymes that 689 may be detected by putative olfactory receptors expressed in the external tissues of starfish. We 690 believe that the new data on the patterns of sea urchin locomotion activity during mass spawning 691 obtained in the present study will serve as the physiological basis for the search for biomolecules 692 that may play a role in pheromones in this group of echinoderms.

693

694 CONCLUSION

695 Our results show that two sea urchin species with planktotrophic larvae, S. intermedius and $M$. 696 nudus, which were monitored in their natural environment, display similar behaviors during mass 
697 spawning events. Males and females of both species responded to some environmental cue(s), 698 most likely phytoplankton, by increasing their locomotion rate $35 \mathrm{~min}$ before the start of 699 spawning. Subsequently, they accelerated until the beginning of and during spawning. Males 700 appeared to be more sensitive to external trigger(s) of spawning than females; therefore, during 701 mass spawning events they began to actively move earlier, in the absence of other spawners.

702 Nonspawners of both species also increased their locomotion activity, but at a later time, in the 703 presence of spawning males and females, and less prominently than spawners. On a vertical 704 surface, both echinoids moved strictly upward, whereas on a flat food substrate, their movement 705 was multidirectional. Spatial distribution analysis showed that although neither echinoid formed

706 707 708

709

710

711

712

713

714

715

716

717

718

719

720

721

722

723

724

725

726

727 spawning aggregations on flat surfaces, the males and, to a much lesser extent, nonspawners approached females during mass spawning.

The temporal dynamics of the numbers of males and females participating in mass spawning were well synchronized in both echinoids so that the maximum numbers of simultaneously spawned sexes coincided. However, males of both sea urchin species exhibited much more active spawning behavior than females: 1) males began to spawn earlier and ended spawning later than females; (2) the spawning duration of males was longer due to the longer pause between sperm batches; and (3) males seemed to be able to spawn several times during the spawning season.

Temporal and quantitative patterns of behavior of the sea urchins $S$. intermedius and $M$. nudus before and during mass spawning may be considered a set of behavioral adaptations aimed at increasing fertilization success. The high sensitivity of males to environmental factor(s), primarily phytoplankton, appears to be a large-scale adaptation characteristic for many broadcast spawners with planktotrophic larvae and is apparently one of the prerequisites for the development of mass spawning events. The nighttime and new and full moon phases apparently to be modulating factors increasing the probability of mass spawning. The longer spawning duration in males compared with females, longer duration of sperm release during mass spawning events compared with that during solitary male spawning, longer durations of sperm release and total time of spawning in males inhabiting the bay with higher levels of phytoplankton and approach of males and females during mass spawning may be considered small-scale adaptations that promote the likelihood of fertilization. 
728

729

730

731

732

733

734

735

736

737

738

739

740

741

742

743

744

745

746

747

748

749

750

751

752

753

754

755

756

757

\section{ACKNOWLEDGEMENTS}

We thank M.Yu. Cheranev for the help in making the underwater installation for video recording and L.Yu. Pavin for assistance in the field.

\section{REFERENCES}

Babcock R, Mundy C, Keesing J, Oliver J. 1992. Predictable and unpredictable spawning events: in situ behavioral data from free-spawning coral reef invertebrates. Invertebrate Reproduction and Development 22:213-228

DOIhttps://doi.org/10.1080/07924259.1992.9672274.

Bronstein O, Kroh A, Loya Y. 2016. Reproduction of the long-spined sea urchin Diadema setosum in the Gulf of Aqaba - implications for the use of gonad-indexes. Scientific Reports 6:29569 DOI https://doi.org/10.1038/srep29569.

Burke RD, Angerer LM, Elphick MR, Humphrey GW, Yaguchi S, Kiyama T, Liang S, Mu X, Agca C, Klein WH, Brandhorst BP, Rowe M, Wilson K, Churcher AM, Taylor JS, Chen N, Murray G, Wang D, Mellott D, Olinski R, Hallböök F, Thorndyke MC. 2006. A genomic view of the sea urchin nervous system. Developmental Biology 300:434-460. DOI https://doi.org/10.1016/j.ydbio.2006.08.007.

Byrne M. 1990. Annual reproductive cycles of the commercial sea urchin Paracentrotus lividus from an exposed intertidal and a sheltered subtidal habitat on the west coast of Ireland. Marine Biology 104: 275-289 DOI https://doi.org/10.1007/BF01313269.

Byrne M, Andrew NL, Worthington DG, Brett PA. 1998. Reproduction in the diadematoid sea urchin Centrostephanus rodgersii in contrasting habitats along the coast of New South Wales, Australia. Marine Biology 132:305-318 DOI https://doi.org/10.1007/s002270050396.

Caballes C, Pratchett M. 2017. Environmental and biological cues for spawning in the crownof-thorns starfish. PLoS ONE 12:e173964 DOI https://doi.org/10.1371/journal.pone.0173964.

Campbell AC, Coppard S, D'abreo C, Tudor-Thomas R. 2001. Escape and aggregation responses of three Echinoderms to conspecific stimuli. Biological Bulletin 201:175-185 DOI https://doi.org/10.2307/1543332. 
758 Coppard SE, Campbell AC. 2005. Lunar periodicities of diadematid echinoids breeding in Fiji.

759

760

761

762

763

764

765

766

767

768

769

770

771

772

773

774

775

776

777

778

779

780

781

782

783

784

785

786

787

788 Coral Reefs 24:324-332 DOI https://doi.org/10.1007/s00338-005-0491-5.

Crimaldi JP, Zimmer RK. 2014. The physics of broadcast spawning in benthic invertebrates. Annual Review of Marine Science 6:141-165 https://doi.org/10.1146/annurev-marine010213-135119.

Efron B, Tibshirani RJ. 1993. An Introduction to the Bootstrap. New York: Chapman \& Hall.

Egea E, Merigot B, Mahe-Bezac C, Feral J-P, Chenuil A. 2011. Differential reproductive timing in Echinocardium spp.: the first Mediterranean survey allows interoceanic and interspecific comparisons.Comptes Rendus Biologies 334:13-23. DOI https://doi.org/10.1016/j.crvi.2010.10.007.

Gaudette J, Wahle RA, Himmelman JH. 2006. Spawning events in small and large populations of the green sea urchin Strongylocentrotus droebachiensis as recorded using fertilization assays. Limnology and Oceanography 51:1485-1496 DOI https://doi.org/10.4319/10.2006.51.3.1485.

Gladstone W. 1992. Observations of crown-of-thorns starfish spawning. Australian Journal of Marine and Freshwater Research 43: 535-537 DOI https://doi.org/10.1071/MF9920535.

González-Irusta JM, De Cerio FG, Canteras JC. 2010. Reproductive cycle of the sea urchin Paracentrotus lividus in the Cantabrian Sea (northern Spain): environmental effects Journal of the Marine Biological Association of the UK 90:699-709 DOI https://doi.org/10.1017/S002531540999110X.

Guillou M, Lumingas LJL. 1998. The reproductive cycle of the 'blunt' sea urchin. Aquaculture International 6:147-160 DOI https://doi.org/10.1023/A:1009290307840.

Hagman DK, Vize PD. 2003. Mass spawning by two brittle star species, Ophioderma rubicundum and $O$. squamosissimum (Echinodermata: Ophiuroidea), at the Flower Garden Banks, Gulf of Mexico. Bulletin of Marine Science 72:871-876. http://pascalfrancis.inist.fr/vibad/index.php?action=getRecordDetail\&idt=15318963

Hall MR, Kocot KM, Baughman KW, Fernandez-Valverde SL, Gauthier MEA, Hatleberg WL, Krishnan A, McDougall C, Motti CA, Shoguchi E, Wang T, Xiang X, Zhao M, Bose U, Shinzato C, Hisata K, Fujie M, Kanda M, Cummins SF, Satoh N, Degnan SM, Degnan BM. 2017. The crown-of-thorns starfish genome as a guide for biocontrol of this coral reef pest. Nature 544:231-234 DOI https://doi.org/10.1038/nature22033. 
789 Hamel J-F, Mercier A. 1995. Spawning of the sea cucumber Cucumaria frondosa in the St

790

791

792

793

794

795

796

797

798

799

800

801

802

803

804

805

806

807

808

809

810

811

812

813

814

815

816

817

818 Lawrence Estuary, eastern Canada. SPC Beche-de-Mer Information Bulletin 7:12-18.

Hamel J-F, Mercier A. 1996. Gamete dispersion and fertilisation success of the sea cucumber Cucumaria frondosa. SPC Beche-de-Mer Information Bulletin 8:34-40.

Hendler G, Meyer DL. 1982. Ophiuroids Flagrante delicto and notes on the spawning behavior of other echinoderms in their natural habitat. Bulletin of Marine Science 32:600-607. https://www.ingentaconnect.com/contentone/umrsmas/bullmar/1982/00000032/00000002 $\underline{\text { art00019 }}$

Himmelman JH. 1975. Phytoplankton as a stimulus for spawning in three marine invertebrates. Journal of Experimental Marine Biology and Ecology 20:199-214 DOI https://doi.org/10.3354/meps07415.

Himmelman JH, Dumont CP, Gaymer CF, Vallières C, Drolet D. 2008. Spawning synchrony and aggregative behaviour of cold-water echinoderms during multi-species mass spawnings. Marine Ecology Progress Series 361:161-168. DOI https://doi.org/10.3354/meps07415.

Iliffe TM, Pearse JS. 1982. Annual and lunar reproductive rhythms of the sea urchin Diadema antillarum (Philippi) in Bermuda. International Journal of Invertebrate Reproduction 5:139-148 DOI https://doi.org/10.1080/01651269.1982.10553463.

Johnson DW, Ranelletti ME. 2017. Natural spawning of a Hawaiian sea urchin, Tripneustes gratilla. Invertebrate Biology 136:31-36 DOI https://doi.org/10.1111/ivb.12158.

King CK, Hoegh-Guldberg O, Byrne M. 1994. Reproductive cycle of Centrostephanus rodgersii (Echinoidea), with recommendations for the establishment of a sea urchin fishery in New South Wales. Marine Biology 120:95-106 DOI https://doi.org/10.1007/BF00381945.

Lamare MD, Stewart BG. 1998. Mass spawning by the sea urchin Evechinus chloroticus (Echinodermata: Echinoidea) in New Zealand fiord. Marine Biology 132:135-140 DOI https://doi.org/10.1007/s002270050379.

Lauzon-Guay J-S, Scheibling RE, Barbeau MA. 2006. Movement patterns in the green sea urchin, Strongylocentrotus droebachiensis. Journal of the Marine Biological Association of the UK 86:167-174 DOI https://doi.org/10.1017/S0025315406012999. 
819 Lessios HA. 1991. Presence and absence of monthly reproductive rhythms among eight

820

821

822

823

824

825

826

827

828

829

830

831

832

833

834

835

836

837

838

839

840

841

842

843

844

845

846

847

848

849

Caribbean echinoids off the coast of Panama. Journal of Experimental Marine Biology and Ecology 153:27-47 DOI https://doi.org/10.1016/S0022-0981(05)80004-8.

Levitan DR. 1998. Sperm limitation, sperm competition and sexual selection in external fertilizers. In: Birkhead T, Moller A, eds. Sperm Competition and Sexual Selection. San Diego: Academic Press, 173-215 DOI https://doi.org/10.1016/B978-0-12-1005436.X5022-3.

Levitan DR. 2002. Density-dependent selection on gamete traits in three congeneric sea urchins. Ecology 83:464-479 DOI https://doi.org/10.1890/00129658(2002)083[0464:DDSOGT72.0.CO;2.

Levitan DR. 2005. Sex-specific spawning behavior and its consequences in an external fertilizer. American Naturalist 165:682-694. DOI https://doi.org/10.1086/429733.

Lotterhos K, Levitan DR. 2010. Gamete release and spawning behavior in broadcast spawning marine invertebrates. In: Leonard JL, Cordoba-Aguilar A, eds. The Evolution of Primary Sexual Characters in Animals. Oxford, UK: Oxford University Press, 99-120.

Mann KH, Wright JLC, Welsford BE, Hatfield E. 1984. Response of the sea urchin Strongylocentrotus droebachiensis (O. F. Müller) to water-borne stimuli from potential predators and potential food algae. Journal of Experimental Marine Biology and Ecology 79:233-244 DOI https://doi.org/10.1016/0022-0981(84)90197-7.

McCarthy DA, Young CM. 2004. Effects of water-borne gametes on the aggregation behavior of Lytechinus variegatus. Marine Ecology Progress Series 283:191-198 DOI 10.3354/meps283191.

McEuen FS. 1988. Spawning behaviors of northeast Pacific sea cucumbers (Holothuroidea: Echinodermata). Marine Biology 98:565-585 DOI https://doi.org/10.1007/BF00391548.

Mercier A, Hamel J-F. 2009. Endogenous and exogenous control of gametogenesis and spawning in echinoderms. Advances in Marine Biology 55:1-302 DOI 10.1016/S00652881(09)55001-8.

Mercier A, and Hamel JF. 2010. Synchronized breeding events in sympatric marine invertebrates: role of behavior and fine temporal windows in maintaining reproductive isolation. Behavioral Ecology and Sociobiology 64:1749-1765 DOI https://doi.org/10.1007/s00265-010-0987-Z.

PeerJ reviewing PDF | (2020:10:53402:1:0:NEW 28 Dec 2020) 
850 Minchin D. 1992. Multiple species, mass spawning events in an Irish sea lough: the effect of

851

852

853

854

855

856

857

858

859

860

861

862

863

864

865

866

867

868

869

870

871

872

873

874

875

876

877

878

879

temperatures on spawning and recruitment of invertebrates. Invertebrate

Reproductionand Development 22:229-238 DOI https://doi.org/10.1080/07924259.1992.9672275.

Olive PJW. 1995. Annual breeding cycles in marine invertebrates and environmental temperature: probing the proximate and ultimate causes of reproductive synchrony. Journal of Thermal Biology 20:79-90 DOI https://doi.org/10.1016/0306-4565(94)00030M.

Pearse JS, McClary DJ, Sewell MA, Austin WC, Perez-Ruzafa A, Byrne M. 1988. Simultaneous spawning of six species of Echinoderms in Barkley Sound, British Columbia. International Journal of Invertebrate Reproduction 14:279-288 DOI https://doi.org/10.1080/01688170.1988.10510385.

Raible F, Tessmar-Raible K, Arboleda E, Kaller T, Bork P, Arendt D, Arnone MI. 2006. Opsins and clusters of sensory G-protein-coupled receptors in the sea urchin genome. Developmental Biology 300:461-475 DOI 10.1016/j.ydbio.2006.08.070.

Reuter KE, Levitan DR. 2010. Influence of sperm and phytoplankton on spawning in the echinoid Lytechinus variegatus.Biological Bulletin 219:198-206 DOI 10.1086/BBLv219n3p198.

Run J-Q, Chen C-P, Chang K-H, Chia F-S. 1988. Mating behavior and reproductive cycle of Archaster typicus (Echinodermata: Asteroidea). Marine Biology 99:247-253 DOI https://doi.org/10.1007/BF00391987.

Slattery M, Bosch I. 1993. Mating behavior of a brooding antarctic asteroid, Neosmilaster georgianus. Invertebrate Reproductionand Development 24:97-102 DOI https://doi.org/10.1080/07924259.1993.9672338.

Spyksma AJP, Taylor RB, Shears NT. 2017. Predation cues rather than resource availability promote cryptic behaviour in a habitat-forming sea urchin. Oecologia 183:821-829 DOI 10.1007/s00442-017-3809-4.

Starr M, Himmelman JH, Therriault JC. 1993. Environmental control of green sea urchin, Strongylocentrotus droebachiensis, spawning in St Lawrence estuary. Canadian Journal of Fisheries and Aquatic Sciences 50:894-901 DOI https://doi.org/10.1139/f93-103. 
880 Starr M, Himmelman JH, Therriault JC. 1990. Direct coupling of marine invertebrate

881

882

883

884

885

886

887

888

889

890

891

892

893

894

895

896

897

898

899

900

901

902

903

904

905

906

907

908 spawning with phytoplankton blooms. Science 247:1070-1074 DOI

10.1126/science.247.4946.1071.

Starr M, Himmelman JH, Therriault JC. 1992. Isolation and properties of a substance from the diatom Phaeodactylum tricornutum which induces spawning in the sea urchin Strongylocentrotus droebachiensis. Marine Ecology Progress Series 79:275-287 DOI 10.3354/meps079275.

Thomas FIM. 1994. Physical properties of gametes in three sea urchin species. Journal of Experimental Biology 194: 263-284.

Thorson G. 1950. Reproductive and larval ecology of marine bottom invertebrates. Biological Reviews 25:1-45 DOI https://doi.org/10.1111/j.1469-185X.1950.tb00585.x.

Tominaga H, Nakamura S, Komatsu M. 2004. Reproduction and development of the conspicuously dimorphic brittle star Ophiodaphne formata (Ophiuroidea). Biological Bulletin 206:25-34 DOI 10.2307/1543195.

Tsuji S, Yoshiya M, Tanaka M, Kuwahara A, Uchino K. 1989. Seasonal changes in distribution and ripeness of gonad of a sea urchin Strongylocentrotus nudus in the western part of Wakasa Bay. Bulletin of the Kyoto Institute of Oceanic and Fishery Science (Japan) 12:15-21.

Unger B, Lott C. 1994. In-situ studies on the aggregation behaviour of the sea urchin Sphaerechinus granularis Lam. (Echinodermata: Echinoidea). In: David B, Guille A, Feral JP, Roux M, eds. Echinoderms trough Time: Proceedings of the 8th International Echinoderm Conference, Dijon, France. Rotterdam: Balkema, 913-917.

Wangensteen OS, Turon X, Palacín C. 2016. Reproductive strategies in marine invertebrates and the structuring of marine animal forests. In: Rossi S, ed. Marine Animal Forests. Springer International Publishing AG, 1-24. DOI https://doi.org/10.1007/978-3-31921012-4 52.

Yund P.O., Meidel S.K. 2003. Sea urchin spawning in benthic boundary layers: are eggs fertilized before advecting away from females? Limnology and Oceanography 48(2):795-801 DOI https://doi.org/10.4319/10.2003.48.2.0795. 
909 Zhadan PM, Vaschenko MA. 2019. Long-term study of behaviors of two cohabiting sea urchin

910

911

912

913

914

915

916

917

918

919

920

921

922

923

924

925

926

927 species, Mesocentrotus nudus and Strongylocentrotus intermedius, under conditions of high food quantity and predation risk in situ. PeerJ 7:e8087 DOI 10.7717/peerj.8087.

Zhadan PM, Vaschenko MA, Almyashova TN. 2015. Spawning failure in the sea urchin Strongylocentrotus intermedius in the northwestern Sea of Japan: potential environmental causes. Journal of Experimental Marine Biology and Ecology 465:11-23 DOI http://dx.doi.org/10.1016/j.jembe.2014.12.017.

Zhadan PM, Vaschenko MA, Almyashova TN. 2017. Effects of environmental factors on reproduction of the sea urchin Strongylocentrotus intermedius In: Agnello M, ed. Sea urchin - from environment to aquaculture and biomedicine. Reijeka: INTECH, 35-69 DOI http://dx.doi.org/10.5772/intechopen.69511.

Zhadan PM, Vaschenko MA, Lobanov VB, Sergeev AF, Kotova SA. 2016. Fine-scale temporal study of the influence of hydrobiological conditions on the spawning of the sea urchin Strongylocentrotus intermedius. Marine Ecology Progress Series 550:147-161 DOI https://doi.org/10.3354/meps11678.

Zhadan PM, Vaschenko MA, Ryazanov SD. 2018. Assessing the effect of environmental factors on the spawning activity of the sea urchin Strongylocentrotus intermedius through video recording observations. Marine Ecology Progress Series 588:101-119 DOI https://doi.org/10.3354/meps12436. 


\section{Table $\mathbf{1}$ (on next page)}

Locations and dates of mass spawning events in the sea urchins Strongylocentrotus intermedius and Mesocentrotus nudus. 
1 Table 1 Locations and dates of mass spawning events in the sea urchins Strongylocentrotus intermedius and Mesocentrotus

2 nudus.

\begin{tabular}{|c|c|c|c|c|c|c|c|}
\hline Location & Species & $\begin{array}{l}\text { Total } \\
\text { number of } \\
\text { sea urchins }\end{array}$ & $\begin{array}{l}\text { Percentage of } \\
\text { spawning sea } \\
\text { urchins }\end{array}$ & Date & $\begin{array}{l}\text { Number of full } \\
\text { tracks of males / } \\
\text { total number of } \\
\text { males }\end{array}$ & $\begin{array}{l}\text { Number of full } \\
\text { tracks of females / } \\
\text { total number of } \\
\text { females }\end{array}$ & $\begin{array}{l}\text { Sheet } \\
\text { number in } \\
\text { Table S1 }\end{array}$ \\
\hline Kievka Bay & S. intermedius & 24 & 43 & 16.08 .2014 & $3 / 7$ & $3 / 3$ & 1 \\
\hline Kievka Bay & S. intermedius & 43 & 23 & 03.08 .2015 & $9 / 10$ & $0 / 0$ & 2 \\
\hline Kievka Bay & S. intermedius & 29 & 39 & 03.08.2015 & $7 / 11$ & $0 / 0$ & 3 \\
\hline Kievka Bay & S. intermedius & 38 & 45 & 14.09 .2015 & $12 / 16$ & $1 / 1$ & 4 \\
\hline Kievka Bay & S. intermedius & 56 & 18 & 16.09 .2015 & $3 / 9$ & $1 / 1$ & 5 \\
\hline Alekseev Bay & S. intermedius & 45 & 22 & 17.05 .2016 & $6 / 10$ & $0 / 0$ & 6 \\
\hline Alekseev Bay & S. intermedius & 65 & 26 & 19.05.2016 & $13 / 15$ & $2 / 2$ & 7 \\
\hline Alekseev Bay & S. intermedius & 72 & 28 & 20.05 .2016 & $14 / 19$ & $1 / 1$ & 8 \\
\hline Alekseev Bay & S. intermedius & 66 & 33 & 22.05 .2016 & $12 / 17$ & $5 / 5$ & 9 \\
\hline AlekseevBay & S. intermedius & 39 & 27 & 01.06 .2016 & $5 / 9$ & $1 / 1$ & 10 \\
\hline Alekseev Bay & S. intermedius & 38 & 26 & 02.06 .2016 & $6 / 10$ & $0 / 0$ & 11 \\
\hline Alekseev Bay & S. intermedius & 39 & 26 & 14.07.2018 & $5 / 9$ & $1 / 2$ & 12 \\
\hline Alekseev Bay & M. nudus & 56 & 52 & 13.07.2017 & $8 / 21$ & $5 / 8$ & 13 \\
\hline
\end{tabular}




\begin{tabular}{|c|c|c|c|c|c|c|c|}
\hline Alekseev Bay & M. nudus & 40 & 25 & 19.07.2017 & $6 / 10$ & $0 / 0$ & 14 \\
\hline Alekseev Bay & M. nudus & 38 & 53 & 21.07.2017 & $13 / 20$ & $0 / 0$ & 15 \\
\hline Alekseev Bay & M. nudus & 35 & 40 & 11.07 .2018 & $7 / 11$ & $2 / 3$ & 16 \\
\hline Alekseev Bay & M. nudus & 41 & 27 & 11.07.2018 & $8 / 9$ & $1 / 2$ & 17 \\
\hline Alekseev Bay & M. nudus & 37 & 78 & 13.07 .2018 & $18 / 23$ & $5 / 6$ & 18 \\
\hline Alekseev Bay & M. nudus & 63 & 41 & 13.07 .2018 & $13 / 21$ & $3 / 5$ & 19 \\
\hline AlekseevBay & M. nudus & 57 & 18 & 17.07.2018 & $4 / 9$ & $1 / 1$ & 20 \\
\hline Alekseev Bay & M. nudus & 34 & 32 & 17.07.2018 & $8 / 9$ & $2 / 2$ & 21 \\
\hline Alekseev Bay & M. nudus & 37 & 49 & 16.08 .2018 & $14 / 16$ & $2 / 2$ & 22 \\
\hline Alekseev Bay & M. nudus & 50 & 42 & 21.07.2019 & $10 / 18$ & $2 / 3$ & 23 \\
\hline Alekseev Bay & M. nudus & 47 & 38 & 26.07.2019 & $11 / 16$ & $1 / 2$ & 24 \\
\hline
\end{tabular}




\section{Table 2 (on next page)}

Temporal parameters of spawning of the sea urchins Strongylocentrotus intermedius and Mesocentrotus nudus participating in mass spawning events.

The data for 15 females (f) and 96 males (m) of $S$. intermedius and 24 females and 119 males of M. nudus are presented as the median and range (in parentheses). " $n$ " is the number of measurements for each parameter. The Mann-Whitney test was used to reveal intersex and interspecies differences. 


\begin{tabular}{|c|c|c|c|c|c|c|c|c|}
\hline \multirow{2}{*}{ Parameter } & \multicolumn{2}{|c|}{ S. intermedius } & \multicolumn{2}{|c|}{ M. nudus } & \multicolumn{2}{|c|}{ Intersex comparison } & \multicolumn{2}{|c|}{ Interspecies comparison } \\
\hline & Male & Female & Male & Female & S. intermedius & M. nudus & Males & Females \\
\hline $\begin{array}{l}\text { Release duration } \\
\text { of one gamete } \\
\text { batch (min) }\end{array}$ & $\begin{array}{l}3 \\
(1-90) \\
n=390\end{array}$ & $\begin{array}{l}4 \\
(1-34) \\
n=38\end{array}$ & $\begin{array}{l}2 \\
(1-34) \\
n=379\end{array}$ & $\begin{array}{l}6 \\
(1-21) \\
n=50\end{array}$ & $\begin{array}{l}\mathrm{m} \approx \mathrm{f} \\
U=6238 \\
p=0.1040\end{array}$ & $\begin{array}{l}\mathrm{m}<\mathrm{f} \\
U=6148 \\
p=0.0001\end{array}$ & $\begin{array}{l}\mathrm{m}_{\text {int }}>\mathrm{m}_{\text {nud }} \\
U=66350 \\
p=0.0049\end{array}$ & $\begin{array}{l}\mathrm{f}_{\text {int }} \approx \mathrm{f}_{\text {nud }} \\
U=869 \\
p=0.4966\end{array}$ \\
\hline $\begin{array}{l}\text { Total duration of } \\
\text { gamete release } \\
\text { (min) }\end{array}$ & $\begin{array}{l}13.5 \\
(1-92) \\
n=96\end{array}$ & $\begin{array}{l}14 \\
(2-61) \\
n=15\end{array}$ & $\begin{array}{l}9 \\
(1-62) \\
n=119\end{array}$ & $\begin{array}{l}14 \\
(3-37) \\
n=24\end{array}$ & $\begin{array}{l}\mathrm{m} \approx \mathrm{f} \\
U=683.5 \\
p=0.6567\end{array}$ & $\begin{array}{l}\mathrm{m} \approx \mathrm{f} \\
U=1611 ; \\
p=0.5833\end{array}$ & $\begin{array}{l}\mathrm{m}_{\text {int }}>\mathrm{m}_{\text {nud }} \\
U=4847 \\
p<0.0067\end{array}$ & $\begin{array}{l}\mathrm{f}_{\text {int }} \approx \mathrm{f}_{\text {nud }} \\
U=181 ; \\
p=0.5804\end{array}$ \\
\hline $\begin{array}{l}\text { Time interval } \\
\text { between gamete } \\
\text { batches (min) }\end{array}$ & $\begin{array}{l}4 \\
(0-162) \\
n=292\end{array}$ & $\begin{array}{l}1.5 \\
(0-35) \\
n=28\end{array}$ & $\begin{array}{l}4 \\
(0-79) \\
n=282\end{array}$ & $\begin{array}{l}1 \\
(0-11) \\
n=37\end{array}$ & $\begin{array}{l}\mathrm{m}>\mathrm{f} \\
U=2862 ; \\
p=0.0072\end{array}$ & $\begin{array}{l}\mathrm{m}>\mathrm{f} \\
U=2657 \\
p<0.0001\end{array}$ & $\begin{array}{l}\mathrm{m}_{\mathrm{int}} \approx \mathrm{m}_{\mathrm{nud}} \\
U=40895 \\
p=0.8645\end{array}$ & $\begin{array}{l}\mathrm{f}_{\text {int }} \geq \mathrm{f}_{\text {nud }} \\
U=401.5 ; \\
p=0.1148\end{array}$ \\
\hline $\begin{array}{l}\text { Total duration of } \\
\text { intervals between } \\
\text { gamete batches } \\
\text { (min) }\end{array}$ & $\begin{array}{l}15 \\
(0-162) \\
n=96\end{array}$ & $\begin{array}{l}1 \\
(0-50) \\
n=15\end{array}$ & $\begin{array}{l}9 \\
(0-113) \\
n=119\end{array}$ & $\begin{array}{l}0 \\
(0-11) \\
n=24\end{array}$ & $\begin{array}{l}\mathrm{m}>\mathrm{f} \\
U=348.5 ; \\
p=0.001\end{array}$ & $\begin{array}{l}\mathrm{m}>\mathrm{f} \\
U=871.5 \\
p<0.0001\end{array}$ & $\begin{array}{l}\mathrm{m}_{\text {int }}>\mathrm{m}_{\text {nud }} \\
U=4760 \\
p=0.0037\end{array}$ & $\begin{array}{l}\mathrm{f}_{\text {int }} \geq \mathrm{f}_{\text {nud }} \\
U=162.5 ; \\
p=0.062\end{array}$ \\
\hline $\begin{array}{l}\text { Spawning } \\
\text { duration (min) }\end{array}$ & $\begin{array}{l}36 \\
(1-188) \\
n=96\end{array}$ & $\begin{array}{l}24 \\
(2-111) \\
n=15\end{array}$ & $\begin{array}{l}24 \\
(1-140) \\
n=119\end{array}$ & $\begin{array}{l}15 \\
(1-48) \\
n=24\end{array}$ & $\begin{array}{l}\mathrm{m}>\mathrm{f} \\
U=482 ; \\
p=0.0398\end{array}$ & $\begin{array}{l}\mathrm{m}>\mathrm{f} \\
U=1178 ; \\
p=0.0089\end{array}$ & $\begin{array}{l}\mathrm{m}_{\mathrm{int}}>\mathrm{m}_{\mathrm{nud}} \\
U=4423 \\
p=0.0003\end{array}$ & $\begin{array}{l}\mathrm{f}_{\text {int }} \geq \mathrm{f}_{\text {nud }} \\
U=162.5 ; \\
p=0.1826\end{array}$ \\
\hline
\end{tabular}




\section{Table 3(on next page)}

Temporal parameters of spawning of the sea urchin Strongylocentrotus intermedius inhabiting different bays.

The data are presented as the median and range (in parentheses). " $n$ " is the number of measurements for each parameter. The Mann-Whitney test was used to reveal the differences. 


\begin{tabular}{|c|c|c|c|c|c|c|c|c|}
\hline \multirow{2}{*}{ Parameter } & \multicolumn{2}{|c|}{ Alekseev Bay } & \multicolumn{2}{|c|}{ Kievka Bay } & \multicolumn{2}{|c|}{ Intersex comparison } & \multicolumn{2}{|c|}{ Interhabitat comparison } \\
\hline & Male & Female & Male & Female & Alekseev Bay & Kievka Bay & Males & Females \\
\hline $\begin{array}{l}\text { Release duration of } \\
\text { one gamete batch } \\
\text { (min) }\end{array}$ & $\begin{array}{l}4 \\
(1-90) \\
n=257\end{array}$ & $\begin{array}{l}5.5 \\
(1-34) \\
n=22\end{array}$ & $\begin{array}{l}2 \\
(1-13) \\
n=133\end{array}$ & $\begin{array}{l}3 \\
(1-24) \\
n=9\end{array}$ & $\begin{array}{l}\mathrm{m}<\mathrm{f} \\
U=2106 \\
p=0.0449\end{array}$ & $\begin{array}{l}\mathrm{m} \leq \mathrm{f} \\
U=2106 \\
p=0.2847\end{array}$ & $\begin{array}{l}\mathrm{m}_{\mathrm{Alek}}>\mathrm{m}_{\mathrm{Kiev}} \\
U=11580 \\
p<0.0001\end{array}$ & $\begin{array}{l}\mathrm{f}_{\text {Alek }} \geq \mathrm{f}_{\mathrm{Kiev}} \\
U=54.5 ; \\
p=0.0517\end{array}$ \\
\hline $\begin{array}{l}\text { Total duration of } \\
\text { gamete release } \\
\text { (min) }\end{array}$ & $\begin{array}{l}25 \\
(1-92) \\
n=61\end{array}$ & $\begin{array}{l}17 \\
(5-61) \\
n=10\end{array}$ & $\begin{array}{l}6.5 \\
(1-45) \\
n=35\end{array}$ & $\begin{array}{l}7 \\
(2-24) \\
n=5\end{array}$ & $\begin{array}{l}\mathrm{m} \approx \mathrm{f} \\
U=278 \\
p=0.6101\end{array}$ & $\begin{array}{l}\mathrm{m} \approx \mathrm{f} \\
U=85 \\
p>0.9999\end{array}$ & $\begin{array}{l}\mathrm{m}_{\text {Alek }}>\mathrm{m}_{\mathrm{Kiev}} \\
U=433 \\
p<0.0001\end{array}$ & $\begin{array}{l}f_{\text {Alek }} \geq f_{\text {Kiev }} \\
U=15 \\
p=0.0856\end{array}$ \\
\hline $\begin{array}{l}\text { Time interval } \\
\text { between gamete } \\
\text { batches (min) }\end{array}$ & $\begin{array}{l}4 \\
(0-162) \\
n=201\end{array}$ & $\begin{array}{l}2 \\
(0-35) \\
n=21\end{array}$ & $\begin{array}{l}2 \\
(0-35) \\
n=91\end{array}$ & $\begin{array}{l}1 \\
(0-6) \\
n=7\end{array}$ & $\begin{array}{l}\mathrm{m}>\mathrm{f} \\
U=1463 \\
p=0.0192\end{array}$ & $\begin{array}{l}\mathrm{m} \geq \mathrm{f} \\
U=157.5 \\
p=0.0905\end{array}$ & $\begin{array}{l}\mathrm{m}_{\text {Alek }}>\mathrm{m}_{\mathrm{Kiev}} \\
U=6575 \\
p<0.0001\end{array}$ & $\begin{array}{l}\mathrm{f}_{\text {Alek }} \geq \mathrm{f}_{\text {Kiev }} \\
U=401.5 ; \\
p=0.2148\end{array}$ \\
\hline $\begin{array}{l}\text { Total duration of } \\
\text { intervals between } \\
\text { gamete batches } \\
\text { (min) }\end{array}$ & $\begin{array}{l}23 \\
(0-162) \\
n=61\end{array}$ & $\begin{array}{l}4.5 \\
(0-50) \\
n=10\end{array}$ & $\begin{array}{l}7.5 \\
(0-47) \\
n=35\end{array}$ & $\begin{array}{l}0 \\
(0-11) \\
n=5\end{array}$ & $\begin{array}{l}\mathrm{m}>\mathrm{f} \\
U=141.5 ; \\
p=0.0048\end{array}$ & $\begin{array}{l}\mathrm{m}>\mathrm{f} \\
U=36.5 ; \\
p=0.0337\end{array}$ & $\begin{array}{l}\mathrm{m}_{\text {Alek }}>\mathrm{m}_{\mathrm{Kiev}} \\
U=598.5 \\
p=0.0004\end{array}$ & $\begin{array}{l}\mathrm{f}_{\text {Alek }} \geq \mathrm{f}_{\text {Kiev }} \\
U=50 ; \\
p=0.2547\end{array}$ \\
\hline $\begin{array}{l}\text { Spawning duration } \\
\text { (min) }\end{array}$ & $\begin{array}{l}59 \\
(8-188) \\
n=61\end{array}$ & $\begin{array}{l}29 \\
(5-111) \\
n=10\end{array}$ & $\begin{array}{l}20 \\
(1-59) \\
n=35\end{array}$ & $\begin{array}{l}8 \\
(2-24) \\
n=5\end{array}$ & $\begin{array}{l}\mathrm{m}>\mathrm{f} \\
U=186 \\
p=0.04354\end{array}$ & $\begin{array}{l}\mathrm{m} \geq \mathrm{f} \\
U=55 ; \\
p=0.2183\end{array}$ & $\begin{array}{l}\mathrm{m}_{\mathrm{Alek}}>\mathrm{m}_{\mathrm{Kiev}} \\
U=395 \\
p<0.0001\end{array}$ & $\begin{array}{l}f_{\text {Alek }} \geq f_{\text {Kiev }} \\
U=10.5 ; \\
p=0.0799\end{array}$ \\
\hline
\end{tabular}




\section{Table 4 (on next page)}

Temporal parameters of solitary and mass spawning in males of the sea urchins Strongylocentrotus intermedius and Mesocentrotus nudus.

The data are presented as the median and range (in parentheses). " $n$ " is the number of

measurements for each parameter. The Mann-Whitney test was used to reveal differences between solitary and mass spawning. 


\begin{tabular}{|c|c|c|c|c|c|c|}
\hline \multirow[b]{2}{*}{ Parameter } & \multicolumn{3}{|c|}{ Strongylocentrotus intermedius } & \multicolumn{3}{|c|}{ Mesocentrotus nudus } \\
\hline & $\begin{array}{l}\text { Solitary } \\
\text { spawning }\end{array}$ & $\begin{array}{l}\text { Mass } \\
\text { spawning }\end{array}$ & Statistics & $\begin{array}{l}\text { Solitary } \\
\text { spawning }\end{array}$ & $\begin{array}{l}\text { Mass } \\
\text { spawning }\end{array}$ & Statistics \\
\hline $\begin{array}{l}\text { Release duration of one } \\
\text { gamete batch (min) }\end{array}$ & $\begin{array}{l}2 \\
(1-16) \\
n=72\end{array}$ & $\begin{array}{l}4 \\
(1-90) \\
n=257\end{array}$ & $\begin{array}{l}U=7024 \\
p=0.0015\end{array}$ & $\begin{array}{l}2 \\
(1-12) \\
n=52\end{array}$ & $\begin{array}{l}3 \\
(1-34) \\
n=379\end{array}$ & $\begin{array}{l}U=8160 \\
p=0.0396\end{array}$ \\
\hline $\begin{array}{l}\text { Total duration of gamete } \\
\text { release (min) }\end{array}$ & $\begin{array}{l}13 \\
(1-26) \\
n=20\end{array}$ & $\begin{array}{l}25 \\
(4-92) \\
n=61\end{array}$ & $\begin{array}{l}U=372.5 \\
p=0.0069\end{array}$ & $\begin{array}{l}6 \\
(1-23) \\
n=20\end{array}$ & $\begin{array}{l}9 \\
(1-62) \\
n=119\end{array}$ & $\begin{array}{l}U=741 \\
p=0.0021\end{array}$ \\
\hline $\begin{array}{l}\text { Time interval between } \\
\text { gamete batches (min) }\end{array}$ & $\begin{array}{l}4 \\
(0-48) \\
n=36\end{array}$ & $\begin{array}{l}4 \\
(0-162) \\
n=201\end{array}$ & $\begin{array}{l}U=3188 \\
p=0.2551\end{array}$ & $\begin{array}{l}4 \\
(0-48) \\
n=36\end{array}$ & $\begin{array}{l}4 \\
(0-79) \\
n=282\end{array}$ & $\begin{array}{l}U=4916 \\
p=0.7574\end{array}$ \\
\hline $\begin{array}{l}\text { Total duration of intervals } \\
\text { between gamete batches } \\
\text { (min) }\end{array}$ & $\begin{array}{l}6.5 \\
(0-62) \\
n=20\end{array}$ & $\begin{array}{l}23 \\
(0-162) \\
n=61\end{array}$ & $\begin{array}{l}U=277 \\
p=0.0001\end{array}$ & $\begin{array}{l}7 \\
(0-76) \\
n=20\end{array}$ & $\begin{array}{l}9 \\
(0-113) \\
n=119\end{array}$ & $\begin{array}{l}U=1186 \\
p=0.5993\end{array}$ \\
\hline Spawning duration (min) & $\begin{array}{l}20.5 \\
(1-71) \\
n=20\end{array}$ & $\begin{array}{l}59 \\
(8-188) \\
n=61\end{array}$ & $\begin{array}{l}U=218 \\
p<0.0001\end{array}$ & $\begin{array}{l}15 \\
(1-99) \\
n=20\end{array}$ & $\begin{array}{l}24 \\
(1-140) \\
n=119\end{array}$ & $\begin{array}{l}U=943.5 \\
p=0.0588\end{array}$ \\
\hline
\end{tabular}




\section{Table 5 (on next page)}

Changes in the step length $(\mathrm{cm})$ of the sea urchins Strongylocentrotus intermedius and Mesocentrotus nudus during different periods of mass spawning events.

The medians of step length were compared with the Kruskal-Wallis test followed by Dunn's multiple comparison test. " $n$ " is the number of full tracks of sea urchin movement; "ns" - not significant. 


\begin{tabular}{|c|c|c|c|c|c|c|c|c|c|}
\hline \multirow{2}{*}{ Interval } & \multirow{2}{*}{$\begin{array}{l}\text { Statistical } \\
\text { parameter }\end{array}$} & \multicolumn{2}{|c|}{ S. intermedius } & \multicolumn{2}{|l|}{ M. nudus } & \multicolumn{2}{|c|}{ Leading males } & \multicolumn{2}{|c|}{$\begin{array}{l}\text { Nonspawning } \\
\text { individuals }\end{array}$} \\
\hline & & Male & Female & Male & Female & $\begin{array}{l}\text { S. } \\
\text { intermedius }\end{array}$ & M. nudus & $\begin{array}{l}\text { S. } \\
\text { intermedius }\end{array}$ & M. nudus \\
\hline \multirow{3}{*}{ Control } & $n$ & 96 & 15 & 119 & 24 & 21 & 33 & 85 & 50 \\
\hline & Median & 0 & 0.14 & 0.035 & 0 & 0 & 0 & 0.1 & 0.071 \\
\hline & Range & $0-9.9$ & $0-7.8$ & $0-13.1$ & $0-11.5$ & $0-4.5$ & $0-11.4$ & $0-7.1$ & $0-4.6$ \\
\hline \multirow[t]{2}{*}{ Prespawning } & Median & 0.14 & 0.36 & 0.1 & 0.14 & 0.1 & 0.1 & 0 & 0 \\
\hline & Range & $0-8.0$ & $0-7.6$ & $0-13.2$ & $0-13.6$ & $0-6.4$ & $0-8.6$ & $0-2.1$ & $0-13.0$ \\
\hline \multirow[t]{2}{*}{ Spawning } & Median & 0.32 & 0.27 & 0.47 & 0.42 & 0.45 & 0.42 & 0.1 & 0.1 \\
\hline & Range & $0-14.0$ & $0-7.0$ & $0-12.2$ & $0-14.2$ & $0-8.0$ & $0-13.3$ & $0-10.78$ & $0-9.5$ \\
\hline \multirow{2}{*}{$\begin{array}{l}\text { Prespawning } \\
\text { / Control } \\
\text { comparison }\end{array}$} & $\begin{array}{l}\text { Mean rank } \\
\text { diff. }\end{array}$ & 519.1 & 262.7 & 443.6 & 207.6 & 133.4 & 237.1 & -84.28 & -4.1 \\
\hline & $p$ & $<0.0001$ & $<0.0001$ & $<0.0001$ & $<0.0001$ & $<0.0001$ & $<0.0001$ & $\mathrm{~ns}$ & ns \\
\hline \multirow{2}{*}{$\begin{array}{l}\text { Spawning / } \\
\text { Control } \\
\text { comparison }\end{array}$} & $\begin{array}{l}\text { Mean rank } \\
\text { diff. }\end{array}$ & 1869 & 131.8 & 243 & 505.7 & 520.3 & 670.7 & 336.3 & 161.9 \\
\hline & $p$ & $<0.0001$ & $<0.0001$ & $<0.0001$ & $<0.0001$ & $<0.0001$ & $<0.0001$ & $<0.0001$ & $<0.001$ \\
\hline \multirow{2}{*}{$\begin{array}{l}\text { Spawning / } \\
\text { Prespawning } \\
\text { comparison }\end{array}$} & $\begin{array}{l}\text { Mean rank } \\
\text { diff. }\end{array}$ & 1350 & -130.9 & 1995 & 298 & 386.9 & 433.6 & 420.6 & 166 \\
\hline & $p$ & $<0.0001$ & $<0.0001$ & $<0.0001$ & $<0.0001$ & $<0.0001$ & $<0.0001$ & $<0.0001$ & $<0.0001$ \\
\hline
\end{tabular}




\section{Table 6(on next page)}

Comparison of the step length $(\mathrm{cm})$ of leading and outsider sea urchin males during the prespawning period.

The data are presented as the median and range (in parentheses) for 35-min intervals before the start of spawning. The Mann-Whitney test was used for comparison. " $n$ " is the number of full tracks of sea urchin movement. 


\begin{tabular}{l|l|l|l}
\hline Species & Leading males & Outsider males & Statistics \\
\hline $\begin{array}{l}\text { Strongylocentrotus } \\
\text { intermedius }\end{array}$ & 0.1 & 0.14 & $U=355145, p=0.0756$ \\
& $(0-6.4)$ & $(0-6.3)$ & $n=29$ \\
& $n=21$ & 0.14 & \\
Mesocentrotus nudus & 0.1 & $(0-8.4)$ & $U=583245, p=0.2407$ \\
& $(0-8.6)$ & $n=30$ & \\
& $n=33$ & & \\
\hline
\end{tabular}




\section{Table 7 (on next page)}

The distances $(\mathrm{cm})$ from spawners and nonspawners to their common center of mass (CCM) and the center of mass of females (FCM) during sea urchin mass spawning.

The data are presented as the median and range (in parentheses). " $n$ " is the number of full tracks of sea urchin movement. 


\begin{tabular}{|c|c|c|c|c|c|c|c|}
\hline \multirow[b]{2}{*}{ Interval } & \multirow[b]{2}{*}{$\begin{array}{l}\text { Statistical } \\
\text { parameter }\end{array}$} & \multicolumn{3}{|c|}{ Strongylocentrotus intermedius } & \multicolumn{3}{|c|}{ Mesocentrotus nudus } \\
\hline & & $\begin{array}{l}\text { From all } \\
\text { individuals to } \\
\text { CCM }\end{array}$ & $\begin{array}{l}\text { From males } \\
\text { to FCM }\end{array}$ & $\begin{array}{l}\text { From } \\
\text { nonspawners } \\
\text { to FCM } \\
\end{array}$ & $\begin{array}{l}\text { From all } \\
\text { individuals to } \\
\text { CCM }\end{array}$ & $\begin{array}{l}\text { From males to } \\
\text { FCM }\end{array}$ & $\begin{array}{l}\text { From } \\
\text { nonspawners } \\
\text { to FCM }\end{array}$ \\
\hline & $n$ & 131 & 67 & 49 & 165 & 101 & 34 \\
\hline Control & $\begin{array}{l}\text { Median } \\
\text { Range }\end{array}$ & $\begin{array}{l}17.16 \\
1.15-36.91\end{array}$ & $\begin{array}{l}20.50 \\
4.96-46.89\end{array}$ & $\begin{array}{l}23.74 \\
5.92-50.50\end{array}$ & $\begin{array}{l}19.15 \\
0.74-58.80\end{array}$ & $\begin{array}{l}25.06 \\
3.07-68.16\end{array}$ & $\begin{array}{l}30.18 \\
2.58-72.04\end{array}$ \\
\hline Spawning & $\begin{array}{l}\text { Median } \\
\text { Range }\end{array}$ & $\begin{array}{l}13.53 \\
0.19-39.16\end{array}$ & $\begin{array}{l}15.75 \\
2.93-55.13\end{array}$ & $\begin{array}{l}21.62 \\
4.80-54.88\end{array}$ & $\begin{array}{l}16.02 \\
0.15-46.71\end{array}$ & $\begin{array}{l}19.35 \\
1.82-46.69\end{array}$ & $\begin{array}{l}28.43 \\
1.29-101.0\end{array}$ \\
\hline \multirow{3}{*}{$\begin{array}{l}\text { Control / } \\
\text { Spawning } \\
\text { comparison }\end{array}$} & $\begin{array}{l}\text { Mann- } \\
\text { Whitney } U\end{array}$ & 12400000 & 1920000 & 2222000 & 21010000 & 4757000 & 775386 \\
\hline & $p$ & $<0.0001$ & $<0.0001$ & $<0.0001$ & $<0.0001$ & $<0.0001$ & $=0.0007$ \\
\hline & $\begin{array}{l}\text { Number of } \\
\text { values }\end{array}$ & 12746 & 4962 & 5220 & 11106 & 7699 & 3058 \\
\hline
\end{tabular}


Figure 1

Examples of temporal dynamics of the numbers of simultaneously spawning sea urchins during mass spawning events.

(A, C) Strongylocentrotus intermedius. (B, D) Mesocentrotus nudus. (A, B) Spawning of sea urchins of both sexes. (C, D) Spawning of males in the absence of females. Blue and red lines indicate the numbers of males and females, respectively.
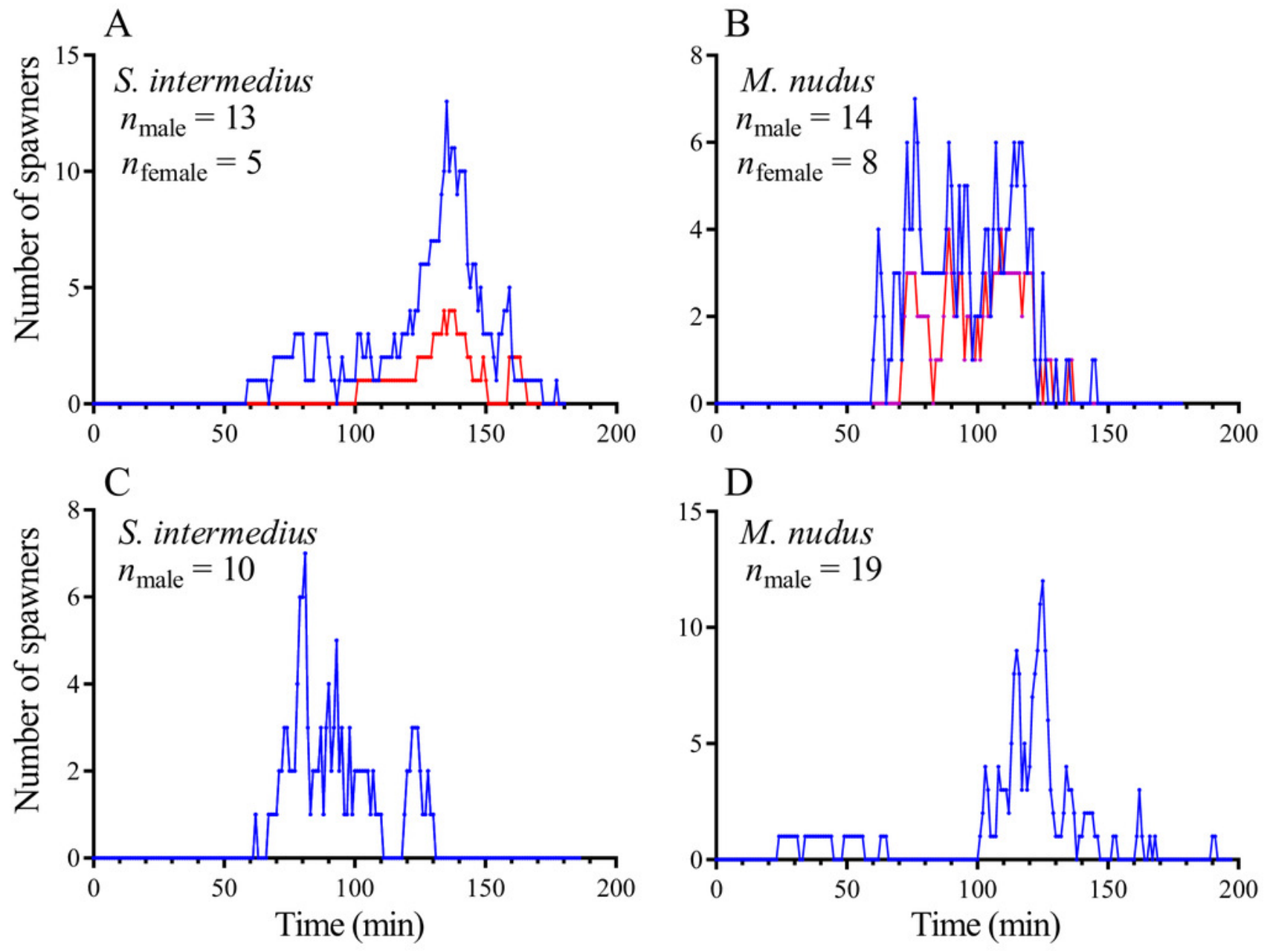


\section{Figure 2}

Temporal dynamics of the numbers of simultaneously spawning males and females of the sea urchins during mass spawning.

(A) Strongylocentrotus intermedius. (B) Mesocentrotus nudus. All data on the numbers of males and females participating in mass spawning events were combined into corresponding pools and aligned on the $\mathrm{X}$-axis at the time point coinciding with the start of the first spawning in each mass spawning event (denoted by a vertical dotted line). Blue and red lines indicate the numbers of males and females, respectively. 

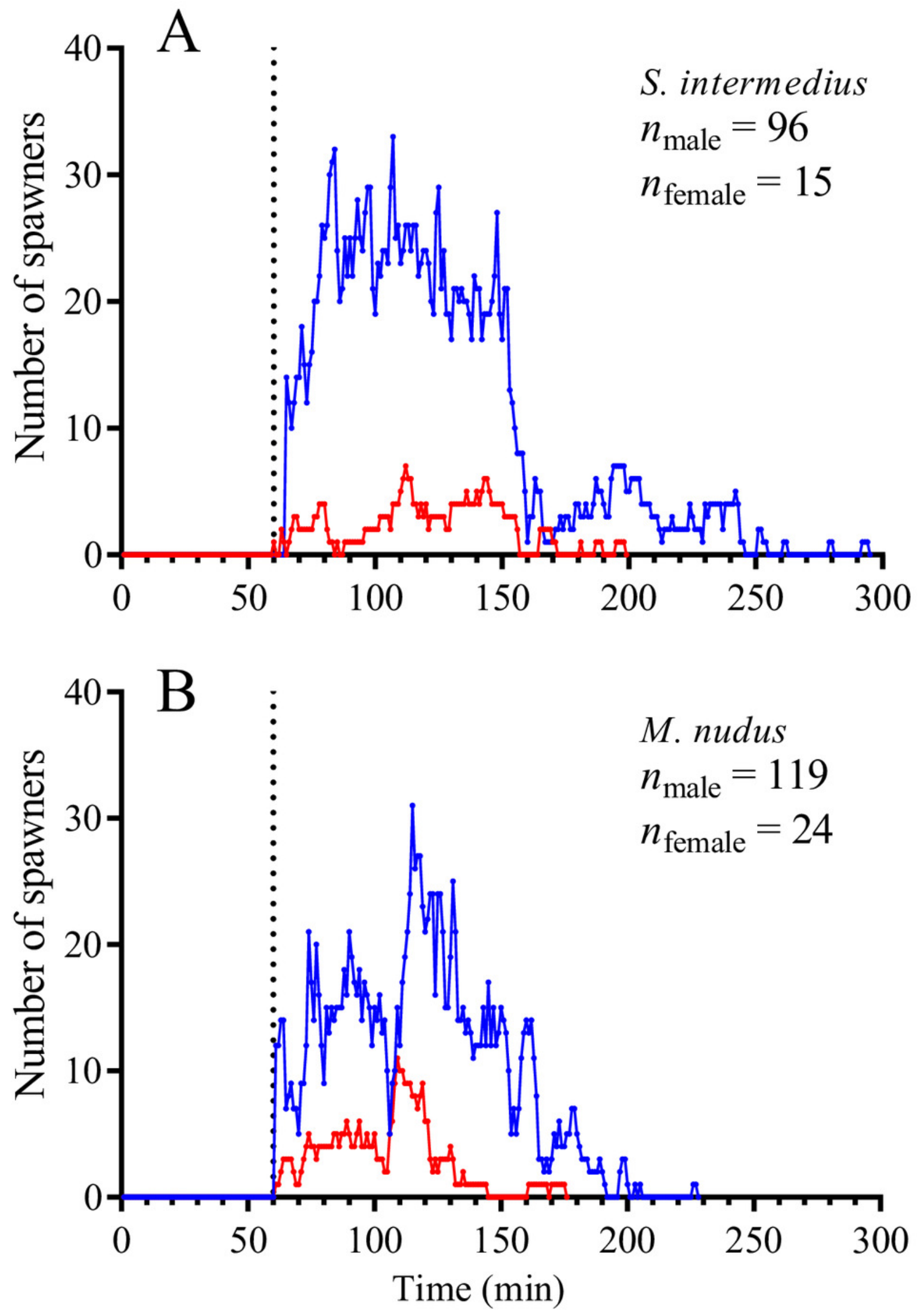


\section{Figure 3}

Temporal dynamics of the locomotion activity of males and females of the sea urchins before and during mass spawning.

(A, B) Strongylocentrotus intermedius. (C, D) Mesocentrotus nudus. The data on the length of sea urchins' steps and the numbers of spawners were combined into corresponding pools and aligned on the $\mathrm{X}$-axis at the time point coinciding with the beginning of spawning of each individual. Vertical dashed lines denote the boundaries of the control, prespawning and spawning intervals. The black solid line denotes the median step length of sea urchins. Vertical lines indicate the interquartile range (IQR). Blue and red lines indicate the numbers of spawning males and females, respectively $(n)$. 

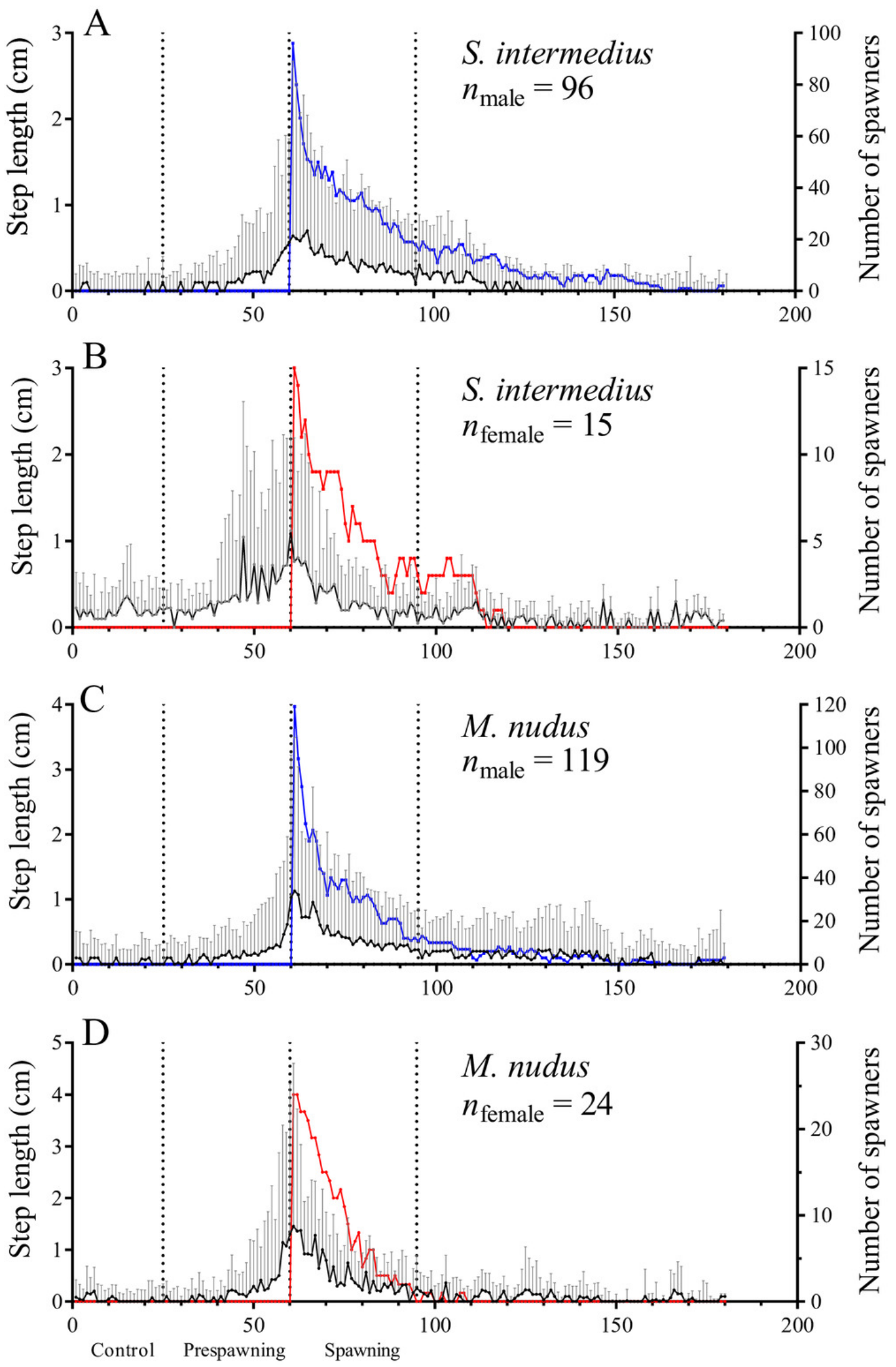

Time (min) 


\section{Figure 4}

Temporal dynamics of the locomotion activity of males that started to spawn first during mass spawning (leading males).

(A) Strongylocentrotus intermedius. (B) Mesocentrotus nudus. The data on the step lengths of leading males and the numbers of spawners were combined into corresponding pools and aligned on the $\mathrm{X}$-axis at the time point coinciding with the beginning of spawning of each male. Vertical dashed lines denote the boundaries of the control, prespawning and spawning intervals. The black solid line denotes the median step length of sea urchins. Vertical lines indicate the interquartile range (IQR). The blue line indicates the number of spawning males (n). 

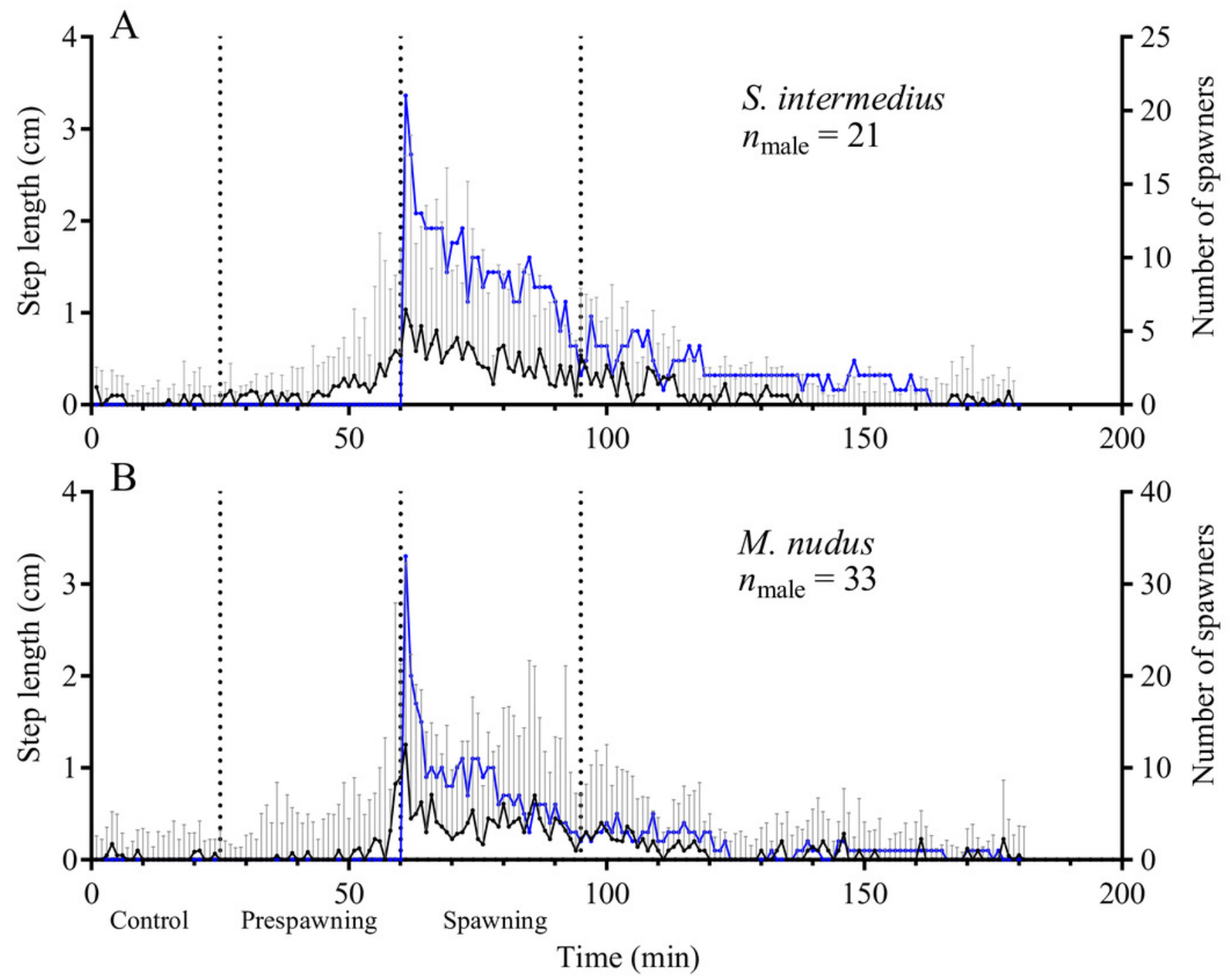


\section{Figure 5}

Temporal dynamics of the locomotion activity of males (blue solid line) and nonspawners (green solid line) during mass spawning events.

(A) Strongylocentrotus intermedius. (B) Mesocentrotus nudus. The data on the step lengths of males and nonspawners were combined into corresponding time series and aligned on the $\mathrm{X}$-axis at the time point coinciding with the beginning of spawning of the first individual in each mass spawning event. Vertical dashed lines denote the boundaries of the control, prespawning and spawning intervals. Vertical solid lines indicate the interquartile range (IQR). 


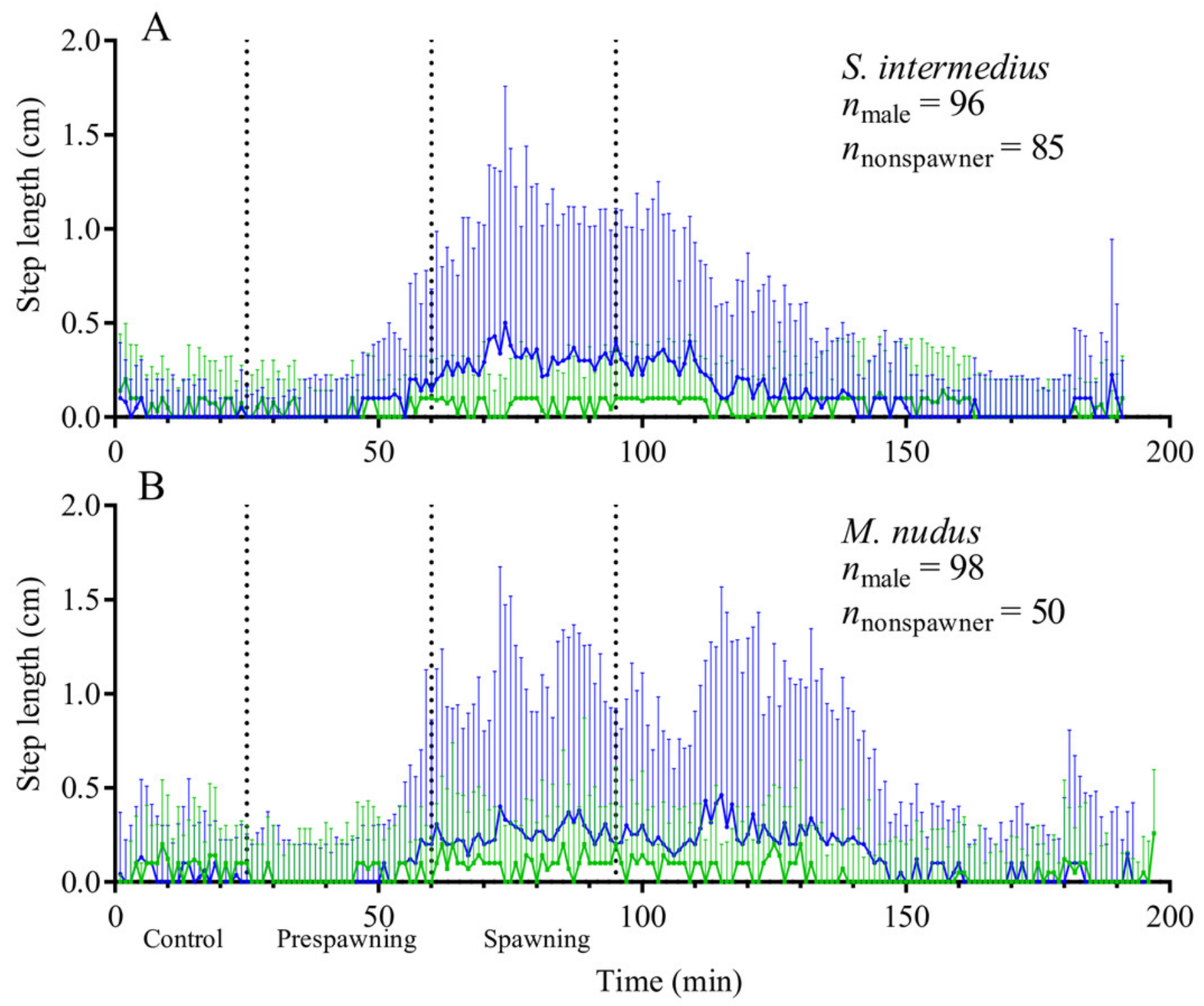




\section{Figure 6}

The changes in distances from males, females and nonspawners to their common center of mass during mass spawning of sea urchins.

When calculating the common center of mass, the conditional mass of spawning individuals was taken as a multiple of the time of gamete release. For nonspawners (denoted by a green color), the conditional mass was taken as a value of 1 . The data for Strongylocentrotus intermedius and Mesocentrotus nudus are denoted by brown and black colors, respectively. $X$-axis: time of the sea urchin movement track $(\min )$. Left $Y$-axis: changes in the distances presented as the mean of differences between the initial and measured 1-min interval distances $(\mathrm{cm})$ and $95 \%$ confidence intervals. Right Y-axis: data on the percentage of spawning males. Vertical dashed lines, from left to right, denote the boundary of the control interval, the time point when the first male in each mass spawning event began to spawn, and the time point when $95 \%$ of males spawned. 


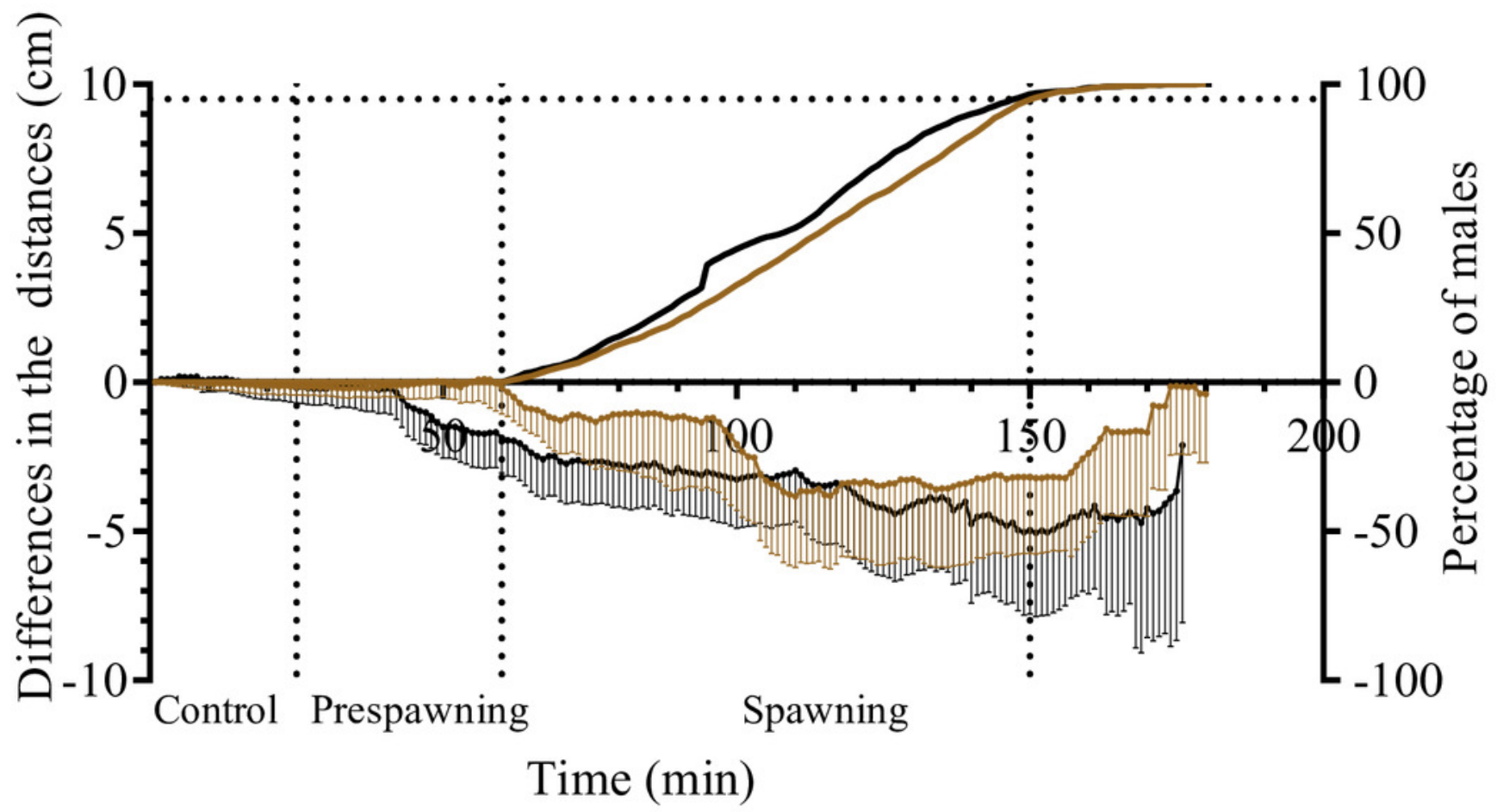




\section{Figure 7}

The changes in distances from males and nonspawners to the center of mass of females during mass spawning of the sea urchins.

(A) Strongylocentrotus intermedius. (B) Mesocentrotus nudus. When calculating the center of mass of females, female conditional mass was taken as a multiple of the time of gamete release. For nonspawners (denoted by a green color), the conditional mass was taken as a value of 1. X-axis: time of the sea urchin movement track (min). Left Y-axes: changes in distances presented as the mean of differences between the initial and measured 1-min interval distances $(\mathrm{cm})$ and $95 \%$ confidence intervals. Right Y-axes: data on the percentage of spawning males. Vertical dashed lines, from left to right, denote the boundary of the control interval, the time point when the first male in each mass spawning event began to spawn, and the time point when $95 \%$ of males spawned. 

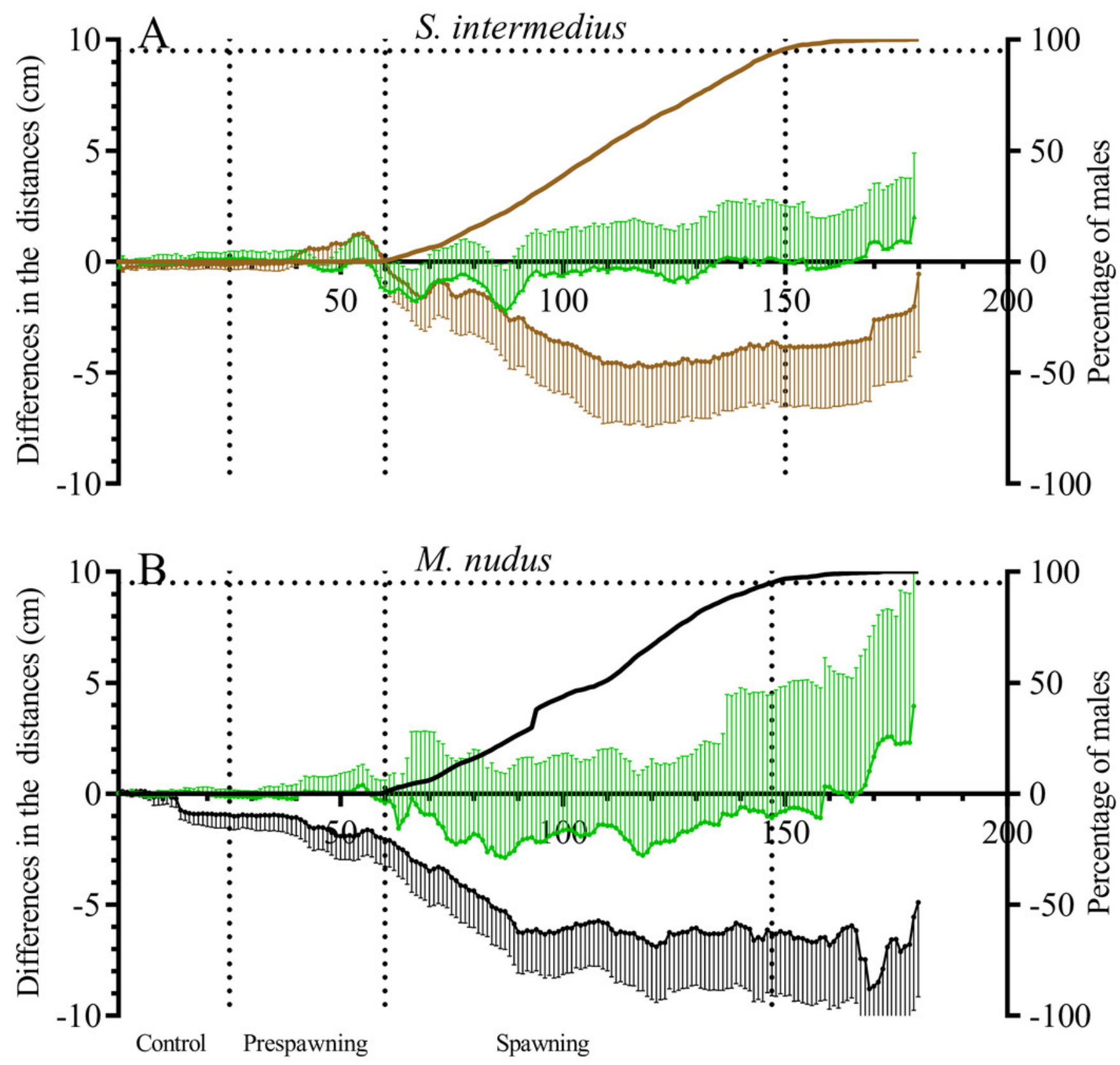

Time (min) 